\title{
THE
}

\section{Metabolic suppression during protracted exposure to hypoxia in the jumbo squid, Dosidicus gigas, living in an oxygen minimum zone}

\author{
Brad A. Seibel \\ University of Rhode Island, seibel@usf.edu \\ N. Sören Häfker \\ Katja Trübenbach \\ Jing Zhang
}

Shannon N. Tessier

See next page for additional authors

Follow this and additional works at: https://digitalcommons.uri.edu/bio_facpubs

Terms of Use

All rights reserved under copyright.

\section{Citation/Publisher Attribution}

Seibel, B. A., Häfker, N. S., Trübenbach, K., Zhang, J., Tessier, S. N., Pörtner, H.-O., Rosa, R., \& Story, K. B. (2014). Metabolic suppression during protracted exposure to hypoxia in the jumbo squid, Dosidicus gigas, living in an oxygen minimum zone. Journal of Experimental Biology, 217, 2555-2568. doi: 10.1242/ jeb.10048

Available at: http://dx.doi.org/10.1242/jeb.100487

This Article is brought to you for free and open access by the Biological Sciences at DigitalCommons@URI. It has been accepted for inclusion in Biological Sciences Faculty Publications by an authorized administrator of DigitalCommons@URI. For more information, please contact digitalcommons-group@uri.edu. 


\section{Authors}

Brad A. Seibel, N. Sören Häfker, Katja Trübenbach, Jing Zhang, Shannon N. Tessier, Hans-Otto Pörtner, Rui Rossa, and Kenneth B. Storey 


\title{
Metabolic suppression during protracted exposure to hypoxia in the jumbo squid, Dosidicus gigas, living in an oxygen minimum
} zone

\author{
Brad A. Seibel ${ }^{1, *}$, N. Sören Häfker ${ }^{2}$, Katja Trübenbach ${ }^{3}$, Jing Zhang ${ }^{4}$, Shannon N. Tessier ${ }^{4}$, Hans-Otto \\ Pörtner $^{2}$, Rui Rosa ${ }^{3}$ and Kenneth B. Storey ${ }^{4}$
}

\begin{abstract}
The jumbo squid, Dosidicus gigas, can survive extended forays into the oxygen minimum zone (OMZ) of the Eastern Pacific Ocean. Previous studies have demonstrated reduced oxygen consumption and a limited anaerobic contribution to ATP production, suggesting the capacity for substantial metabolic suppression during hypoxic exposure. Here, we provide a more complete description of energy metabolism and explore the expression of proteins indicative of transcriptional and translational arrest that may contribute to metabolic suppression. We demonstrate a suppression of total ATP demand under hypoxic conditions ( $1 \%$ oxygen, $\left.P_{\mathrm{O}_{2}}=0.8 \mathrm{kPa}\right)$ in both juveniles $(52 \%)$ and adults $(35 \%)$ of the jumbo squid. Oxygen consumption rates are reduced to $20 \%$ under hypoxia relative to airsaturated controls. Concentrations of arginine phosphate (Arg-P) and ATP declined initially, reaching a new steady state $(\sim 30 \%$ of controls) after the first hour of hypoxic exposure. Octopine began accumulating after the first hour of hypoxic exposure, once Arg-P breakdown resulted in sufficient free arginine for substrate. Octopine reached levels near $30 \mathrm{mmol} \mathrm{g}^{-1}$ after $3.4 \mathrm{~h}$ of hypoxic exposure. Succinate did increase through hypoxia but contributed minimally to total ATP production. Glycogenolysis in mantle muscle presumably serves to maintain muscle functionality and balance energetics during hypoxia. We provide evidence that post-translational modifications on histone proteins and translation factors serve as a primary means of energy conservation and that select components of the stress response are altered in hypoxic squids. Reduced ATP consumption under hypoxia serves to maintain ATP levels, prolong fuel store use and minimize the accumulation of acidic intermediates of anaerobic ATP-generating pathways during prolonged diel forays into the OMZ. Metabolic suppression likely limits active, daytime foraging at depth in the core of the OMZ, but confers an energetic advantage over competitors that must remain in warm, oxygenated surface waters. Moreover, the capacity for metabolic suppression provides habitat flexibility as OMZs expand as a result of climate change.
\end{abstract}

KEY WORDS: Climate change, Vertical migration, Ocean acidification, Critical oxygen partial pressure, Cephalopoda, Epigenetics, Stress response, Antioxidant, Metabolic scaling

${ }^{1}$ University of Rhode Island, Center for Biotechnology and Life Science, Kingston, RI 02881, USA. ${ }^{2}$ Alfred Wegener Institute, Am Handelshafen 12, D-27570 Bremerhaven, Germany. ${ }^{3}$ Laboratório Marítimo da Guia, Centro de Oceanografia, Faculdade de Ciências da Universidade de Lisboa, Av. Nossa Senhora do Cabo, 939, 2750-374 Cascais, Portugal. ${ }^{4}$ Carleton University Institute of Biochemistry, Carleton University, 1125 Colonel By Drive, Ottawa, ON, Canada K1S 5B6.

*Author for correspondence (Seibel@uri.edu)

Received 28 November 2013; Accepted 17 April 2014

\section{INTRODUCTION}

Dosidicus gigas (d'Orbigny 1835) (Ommastrephidae) is a large, apex predator endemic to the Eastern Pacific Ocean (Markaida and Sosa-Nishizaki, 2003; Nigmatullin et al., 2001; Nesis, 1983). Recent interest in D. gigas is motivated, in part, by its poleward range expansion, which may be associated with warmer periods following El Niño/La Niña events and changing ecosystem interactions including food availability, competition and predation (Zeidberg and Robison, 2007). However, some recent studies have suggested a link, whether direct or indirect, between the squid's range expansion and the ongoing deoxygenation in the Eastern Pacific (Stewart et al., 2014; Rosa et al., 2013). Throughout much of the Eastern Tropical Pacific, seawater $P_{\mathrm{O}_{2}}$ declines with depth, from air saturation $(\sim 21 \mathrm{kPa})$ near the surface to less than $5 \%(<1 \mathrm{kPa})$ at intermediate depths $(\sim 250-800 \mathrm{~m})$. These oxygen minimum zones (OMZs) are naturally occurring but may be expanding geographically and shoaling as a result of climate change (Bograd et al., 2008; Stramma et al., 2008; Keeling et al., 2010). The hypoxia in OMZs is already sufficient to restrict the vertical distribution of most apex predators in the ocean (e.g. tuna, swordfish, marlin and sharks; Brill, 1994; Prince and Goodyear, 2006; Vetter et al., 2008; Nasby-Lucas et al., 2009; Stramma et al., 2011; Seibel, 2011), yet the horizontal extent of the OMZ in the eastern Pacific closely mirrors the known distribution of Dosidicus gigas (Nigmatullin et al., 2001).

The typical daily behavior of $D$. gigas involves vertical migrations from near-surface waters at night to mesopelagic depths $(\sim 300 \mathrm{~m})$ during the daytime (Gilly et al., 2006; Zeidberg and Robison, 2007; Matteson et al., 2009; Stewart et al., 2013; Stewart et al., 2014). Recent work confirms that these squid are capable of remaining active at night, maintaining routine metabolism and activity levels down to a critical oxygen partial pressure $\left(P_{\text {crit }}\right)$ of $\sim 1.6 \mathrm{kPa}$ at $10^{\circ} \mathrm{C}(\sim 10 \%$ air saturation) (Trueblood and Seibel, 2013; Gilly et al., 2006). Hypoxia tolerance is partly achieved via adaptations of the respiratory protein hemocyanin that facilitate oxygen loading of the blood at the gills despite a small water-blood oxygen gradient (Seibel, 2013). These adaptations facilitate buffering of the tissue oxygen partial pressure $\left(P_{\mathrm{O}_{2}}\right)$ across a wide range of environmental $P_{\mathrm{O}_{2}}$ values. However, the $P_{\mathrm{O}_{2}}$ typically encountered by $D$. gigas at depth during the daytime is lower than its $P_{\text {crit }}$. Routine oxygen consumption rates in juveniles measured at subcritical $P_{\mathrm{O}_{2}}(0.8 \mathrm{kPa})$ are only $\sim 10 \%$ of those measured in air-saturated seawater (Rosa and Seibel, 2008; Rosa and Seibel, 2010). The measured accumulation of octopine, an indicator of glycolytic flux in cephalopods, was insufficient to meet the energy deficit. This led Rosa and Seibel (Rosa and Seibel, 2010 ) to postulate that total metabolism, including aerobic and anaerobic ATP production, is substantially suppressed. Suppression of total metabolism appears to be a prerequisite for 


\begin{tabular}{|ll|}
\hline List of symbols and abbreviations \\
AEE & anaerobic energy equivalents \\
Arg-P & arginine phosphate \\
$4 \mathrm{EBP}$ & eukaryotic translation initiation factor $4 \mathrm{E}$ binding protein 1 \\
eIF4G & eukaryotic translation initiation factor $4 \mathrm{G}$ \\
eIF2 $\alpha$ & eukaryotic translation initiation factor 2 alpha \\
eIF4E & eukaryotic translation initiation factor $4 \mathrm{E}$ \\
eEF2K & eukaryotic elongation factor 2 kinase \\
eEF2 & eukaryotic elongation factor 2 \\
$\mathrm{GSH}$ & glutathione \\
$\mathrm{HSP}$ & heat shock protein \\
$M$ & body mass \\
$\dot{M}_{\mathrm{O}_{2}}$ & oxygen consumption rate \\
$\mathrm{OMZ}$ & oxygen minimum zone \\
$P_{50}$ & $P_{\mathrm{O}_{2}}$ at $50 \%$ hemocyanin $\mathrm{O}_{2}$ saturation \\
$P_{\mathrm{CO}}$ & CO \\
$P_{\text {crit }}$ & critical oxygen partial pressure \\
$\mathrm{P}_{\mathrm{i}}$ & inorganic phosphate \\
$P_{\mathrm{O}_{2}}$ & oxygen partial pressure \\
$\mathrm{PEP}_{\mathrm{ROV}}$ & phosphoenolpyruvate \\
$\mathrm{R}$ & remotely operated vehicle \\
\end{tabular}

the survival of prolonged bouts of $\mathrm{O}_{2}$ limitation (Guppy and Withers, 1999; Hochachka and Somero, 1984; Bickler and Buck, 2007). Most hypoxia-tolerant organisms are capable of suppressing ATP turnover by $40-95 \%$ and the duration of low oxygen tolerance is proportional to the extent of metabolic suppression (Hand, 1998). However, most species that are used as models of metabolic suppression are relatively sluggish to begin with. A 50\% reduction in ATP usage is quite different for a snail than for an active squid. Dosidicus gigas, like other ommastrephid and loliginid squids, has an oxygen demand that, at equivalent size and temperature, is higher than that of fishes and mammals (O'Dor and Webber, 1986; Seibel, 2007; Seibel and Drazen, 2007; Trueblood and Seibel, 2013).

Hallmarks of metabolic suppression include global suppression of energy-intensive cellular processes such as transcription and translation and the reprioritization of ATP use by vital cell functions (Storey and Storey, 2004). Transcriptional control is achieved via chromatin proteins, particularly histones, which exhibit characteristic post-translational modifications (e.g. acetylation, phosphorylation, methylation) indicative of the accessibility of DNA promoter regions to transcriptional regulatory complexes (Morin and Storey, 2006). With respect to translational competence, key molecular targets are translation initiation factors (Klann and Dever, 2004). Posttranslational modifications and/or interaction with regulatory partners control their accessibility, thereby influencing translational rates (Gingras et al., 1999; Cuesta et al., 2000). Translational suppression may also be regulated during the elongation phase by inhibition of a translation elongation factor (Hizli et al., 2013). Transcriptional regulation factors and translation initiation and elongation factors are known to be important in other models of metabolic rate depression (Larade and Storey, 2002; Hittel and Storey, 2002; Morin and Storey, 2006; Krivoruchko and Storey, 2010a; Krivoruchko and Storey, 2010b; Krivoruchko and Storey, 2010c; Tessier and Storey, 2010) and were targeted in the present study as molecular indices of transcriptional and translational suppression. Despite global suppression of transcription and translation, a common organismal response to environmental stress includes concomitant increases in stress-responsive pathways such as antioxidant defenses and heat shock proteins (HSP) (Storey, 1996; Storey and Storey, 2011; Trübenbach et al., 2012b). As hypoxia-tolerant organisms reduce ATP demand by reducing biosynthetic functions, a greater emphasis may be placed on these macromolecule-preservation strategies. Alternatively, antioxidant metabolites and HSP expression in hypoxia may be a strategy to prevent post-hypoxic oxidative damage during the squid's night-time upwards migration to the surface ocean (Trübenbach et al., 2012b).

Here, we exposed squid ranging from 0.01 to $3.0 \mathrm{~kg}$ to normoxic $\left(P_{\mathrm{O}_{2}}=21 \mathrm{kPa}\right)$ and subcritical oxygen levels $\left(P_{\mathrm{O}_{2}}=0.8 \mathrm{kPa}\right)$ at temperatures consistent with its deeper daytime habitat depth to investigate the metabolic and molecular response to hypoxia. Specifically, we investigated: (i) routine metabolic rates, (ii) accumulation of anaerobic metabolites (octopine, arginine, succinate), (iii) depletion of energy reserves (glycogen, phosphagens and ATP), (iv) the regulation of proteins associated with ATPexpensive processes and (v) stress-response pathways such as HSPs and antioxidant metabolites, which we hypothesize parallel metabolic rate depression in the jumbo squid. The experimental design also allowed us to determine the time course of metabolic changes with prolonged hypoxic exposure.

\section{RESULTS}

\section{Oxygen consumption}

Oxygen consumption rates $\left(\dot{M}_{\mathrm{O}_{2}}\right.$, mol $\left.\mathrm{O}_{2} \mathrm{~g}^{-1} \mathrm{~h}^{-1}\right)$ declined with increasing body mass $(M)$ according to the power equation $\dot{M}_{\mathrm{O}_{2}}=B_{0} M^{b}$, where $B_{0}$ is a normalization constant independent of body mass and $b$ is a scaling coefficient that describes the slope of the relationship (Fig. 1). Normoxic treatments scaled as $\dot{M}_{\mathrm{O}_{2}}=12.1 M^{-0.11}$ while hypoxic treatments are described by $\dot{M}_{\mathrm{O}_{2}}=2.4 M^{-0.12}$. The scaling coefficients were shallow and did not depend significantly on the measurement $P_{\mathrm{O}_{2}}$. However, the normalization constant in hypoxia $\left(B_{0}=2.4\right)$ was significantly lower $\left(\sim 80 \%\right.$ ) than that in normoxia (ANCOVA, $P<0.001$ ). Mean $\dot{M}_{\mathrm{O}_{2}}$ are presented for hypoxic and normoxic juvenile (5.4-13.3 g wet mass) and adult (2-4 kg wet mass) squid in Table 1.

\section{Metabolite accumulation}

The concentrations of ATP, arginine phosphate (Arg-P), octopine, succinate and related metabolites in mantle tissue are presented as means $( \pm$ s.d.) in Table 1 and as a function of the duration of



Fig. 1. Routine oxygen consumption rate $\left(\dot{M}_{\mathrm{O}_{2}}\right)$ of Dosidicus gigas as a function of body mass in air-saturated $\left(\mathrm{P}_{\mathrm{O}_{2}}=21 \mathrm{kPa}\right)$ and hypoxic $\left(P_{\mathrm{O}_{2}}=1.0 \mathrm{kPa}\right)$ water at $10^{\circ} \mathrm{C}$. Colors represent measurements using different methods in different studies: black, end-point methods (Seibel, 2007); blue, flow-through (Rosa and Seibel, 2010) (present study); red, flow-through (present study); and green, continuous (Trueblood and Seibel, 2013). Solid line, filled symbols, $21 \mathrm{kPa}$; dashed line, open symbols, $1.0 \mathrm{kPa}$. Metabolism under normoxia scaled as $\dot{M}_{\mathrm{O}_{2}}=12.1 M^{-0.11}$ (where $M$ is body mass) while under hypoxia, metabolism was described by $\dot{M}_{\mathrm{O}_{2}}=2.4 M^{-0.12}$. 
Table 1. Metabolic changes in juvenile and adult Dosidicus gigas during hypoxic exposure

\begin{tabular}{|c|c|c|c|c|}
\hline & \multicolumn{2}{|c|}{ Normoxic $\left(P_{\mathrm{O}_{2}}=21 \mathrm{kPa}\right)$} & \multicolumn{2}{|c|}{ Hypoxic $\left(P_{\mathrm{O}_{2}}=0.8 \mathrm{kPa}\right)$} \\
\hline & Juvenile & Adult & Juvenile & Adult \\
\hline Mass (g) & $10.0 \pm 3.3$ & $722 \pm 141$ & $9.7 \pm 3.1$ & $939 \pm 390$ \\
\hline Hypoxic exposure (h) & 0 & 0 & $1.3-3.3$ & $2.1-4.3$ \\
\hline$\dot{M}_{\mathrm{O}_{2}}\left(\mu \mathrm{mol} \mathrm{O} \mathrm{O}_{2} \mathrm{~g}^{-1} \mathrm{~h}^{-1}\right)$ & $18.2 \pm 7.7$ & $13.1 \pm 5.5$ & $3.7 \pm 1.7$ & $1.3 \pm 0.6$ \\
\hline \multicolumn{5}{|l|}{ Metabolites $\left(\mu \mathrm{mol} \mathrm{g}{ }^{-1}\right)$} \\
\hline Octopine & $3.8 \pm 1.0$ & $4.9 \pm 3.0$ & $17.8 \pm 9.8$ & $18.1 \pm 14.4$ \\
\hline Arginine & $40.5 \pm 9.0$ & $25.1 \pm 6.8$ & $25.4 \pm 11.2$ & $30.1 \pm 9.7$ \\
\hline Arg-P & $25.2 \pm 5.3$ & $41.9 \pm 18.6$ & $7.2 \pm 2.5$ & $4.7 \pm 2.9$ \\
\hline Succinate & $0.2 \pm 0.1$ & $0.9 \pm 0.2$ & $0.5 \pm 0.2$ & $1.8 \pm 0.5$ \\
\hline ATP & $5.6 \pm 0.5$ & $8.5 \pm 1.6$ & $1.4 \pm 0.3$ & $2.6 \pm 1.6$ \\
\hline $\mathrm{pH}_{\mathrm{i}}$ & - & $7.54 \pm 0.04$ & - & $7.39 \pm 0.05$ \\
\hline $\mathrm{pH}_{\mathrm{e}}$ & - & $7.36 \pm 0.19$ & - & $7.89 \pm 0.09$ \\
\hline$P_{\mathrm{CO}_{2}}(\mathrm{kPa})$ & - & $3.84 \pm 1.55$ & - & $4.63 \pm 2.14$ \\
\hline Total metabolism (ATP equivalents $\mathrm{h}^{-1}$ ) & 82.2 & 53.58 & 39.64 & 34.94 \\
\hline$\%$ Suppression (relative to control) & & & 52 & 35 \\
\hline
\end{tabular}

Mean ( \pm s.d.) oxygen consumption rates $\left(\dot{M}_{\mathrm{O}_{2}}\right)$ and metabolite concentrations in mantle muscle tissue following normoxic and hypoxic exposure in squid at $10^{\circ} \mathrm{C}$. Total metabolism was calculated accounting for the metabolite production and exposure time of each individual squid and cannot be derived precisely from the mean metabolite concentrations in this table.

exposure to $P_{\mathrm{O}_{2}}=0.8 \mathrm{kPa}$ in Figs 2 and 3. Despite the variation in metabolite levels with exposure duration, there were significant differences in all investigated metabolite concentrations comparing mean normoxic (those run continuously in air-saturated water) and hypoxic (those exposed for any duration to $1 \%$ oxygen) conditions in both juveniles and adults $(P<0.05, t$-test). While the absolute values of some metabolites differed between juveniles and adults, the patterns of accumulation and relative changes were similar in the two life stages. They are discussed in combination here and separately below. In both juveniles and adults, the concentration of
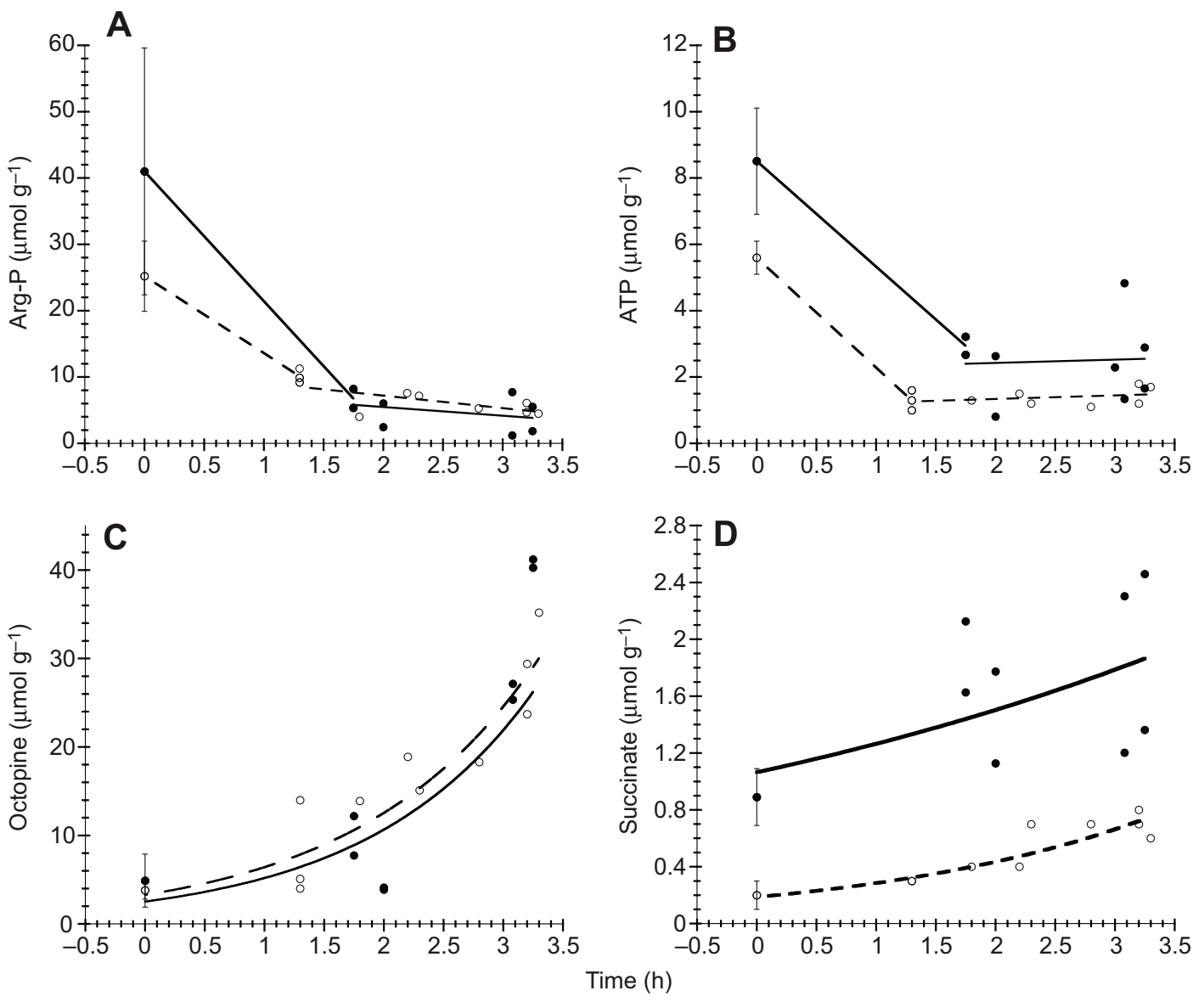

Fig. 2. Juvenile and adult $D$. gigas metabolite measurements during exposure of up to $4 \mathrm{~h}$ in $1 \%$ oxygen. Data at time zero are from squid run continuously in air-saturated water. Open symbols, juveniles; filled symbols, adults. (A) Arginine phosphate (Arg-P) and (B) ATP declined within the first 1-2 $\mathrm{h}$ but then remained constant. (C) Octopine increased in adults $\left(2.5 \mathrm{e}^{0.72 x}, R^{2}=0.82\right)$ and juveniles $\left(3.3 \mathrm{e}^{0.67 x}, R^{2}=0.83\right)$. (D) Succinate increased significantly in juveniles $\left(0.19 \mathrm{e}^{0.42 x}, R^{2}=0.21\right)$ but not in adults with increasing exposure to hypoxia. 



Fig. 3. Aerobic and anaerobic contribution to total ATP production during exposure to hypoxia in $\boldsymbol{D}$. gigas. $(\mathrm{A}, \mathrm{B})$ Contribution of aerobic $\left(\dot{M}_{\mathrm{O}_{2}}\right.$, open circles) and anaerobic energy equivalents (AEE; octopine, Arg-P, ATP and succinate as ATP $\mu \mathrm{mol} \mathrm{g}^{-1} \mathrm{~h}^{-1}$; open squares) to total metabolism (filled circles) in (A) juvenile and (B) adult squid. (C) The rate (squares) and total accumulation (circles) of AEE in juveniles (filled symbols) and adults (open symbols).

inorganic phosphate $\left(\mathrm{P}_{\mathrm{i}}\right)$ more than doubled during hypoxia (data not shown). The Arg-P concentration displayed a drop by almost $90 \%$ and ATP was reduced to $30 \%$ of the control concentration by the end of the longest exposures. The drop in Arg-P was mirrored by the rise in free arginine, which was ultimately incorporated into octopine (Fig. 2A,C). Octopine was elevated 4-fold (to $\sim 30-40 \mu \mathrm{mol} \mathrm{g}^{-1}$ wet mass) by the end of the experiment relative to normoxic controls $\left(5 \mu \mathrm{mol} \mathrm{g}{ }^{-1}\right.$; Fig. $2 \mathrm{C}$, Table 1). Intracellular succinate concentration accumulated exponentially with hypoxic exposure and was doubled, relative to controls, in the longest durations (Fig. 2D). Intracellular glycogen levels, measured only in adults, also declined significantly during hypoxia compared with normoxic conditions (mean control value was $324.8 \pm 80.7$ and mean hypoxia value was $73.9 \pm 9.6 \mu \mathrm{mol}$ glucosyl units $\mathrm{g}^{-1}$ wet mass).

There was no significant difference between juveniles and adults in the levels of octopine at any particular duration of hypoxic exposure or in its rate of accumulation between juveniles and adults (ANCOVA, $P>0.05$; Fig. 2C). While the rates of accumulation were similar in juveniles and adults, the total succinate levels were significantly higher in adults (ANCOVA, $P<0.05$; Fig. 2D). Similarly, control levels of both ATP and Arg-P were significantly higher in adults and both declined by $\sim 60 \%$ after $1 \mathrm{~h}$ of hypoxic exposure (Fig. 2A,B). Arg-P levels in juveniles declined by an additional $50 \%$ over the next few hours while adult levels remained constant following the initial decline.

\section{Total metabolism}

Under hypoxia, the total metabolic rate, measured as the sum of ATP derived from pathways that result in anaerobic energy equivalents (AEE) and the ATP derived from oxidative phosphorylation, was reduced by $52 \%$ and $35 \%$ compared with that measured in air-saturated seawater in juvenile and adult squid, respectively. The contribution of ATP and Arg-P to AEE was high in the early stages of hypoxic exposure while the glycolytic (octopine) and mitochondrial (succinate) contribution increased following $1 \mathrm{~h}$ of exposure (Fig. 2). These contributions offset each other such that the total anaerobic contribution to ATP consumption was constant during hypoxic exposure and accounted for $\sim 50 \%$ of the total metabolic rate under hypoxia (Fig. 3). $\dot{M}_{\mathrm{O}_{2}}$ declined slightly with continuing exposure to hypoxia. As a result, the total metabolic rate also declined slightly through the experimental hypoxia treatment (Fig. 3A,B). AEE production was significantly higher in hypoxic adults $\left(27.26 \pm 3.33 \mu \mathrm{mol} \mathrm{l}^{-1}\right.$ ATP $\left.\mathrm{g}^{-1} \mathrm{~h}^{-1}\right)$ than in hypoxic juveniles $\left(19.92 \pm 4.16 \mu \mathrm{mol} \mathrm{l}^{-1}\right.$ ATP g ${ }^{-1} \mathrm{~h}^{-1} ; t$-test; $\left.P<0.05\right)$.

\section{Acid-base balance}

The intracellular $\mathrm{pH}\left(\mathrm{pH}_{\mathrm{i}}\right)$ values in the mantle tissue of the adult normoxic control animals varied between 7.46 and 7.62 with a mean ( \pm s.d.) of $7.55 \pm 0.04$. In the hypoxic adults, $\mathrm{pH}_{\mathrm{i}}$ varied from 7.31 to 7.50 and the mean was $7.39 \pm 0.05$ (Table 1). $\mathrm{pH}_{\mathrm{i}}$ declined progressively during continuing hypoxic exposure. Because octopine increased exponentially with hypoxic exposure duration, $\mathrm{pH}_{\mathrm{i}}$ and octopine are correlated, but not linearly (Fig. 4A). Under hypoxia the intracellular $\mathrm{CO}_{2}$ partial pressure $\left(P_{\mathrm{CO}_{2}}\right.$, mean \pm s.d.: $0.61 \pm 0.28 \mathrm{kPa})$ was not significantly different $(P>0.05)$ from that under normoxia (mean \pm s.d.: $0.51 \pm 0.20 \mathrm{kPa}$ ). Extracellular (hemolymph) $\mathrm{pH}\left(\mathrm{pH}_{\mathrm{e}}\right)$ increased significantly during hypoxia from $7.36 \pm 0.19$ under control conditions to $7.89 \pm 0.09$ in the hypoxic treatment $(P>0.05)$. Changes in $\mathrm{pH}_{\mathrm{i}}$ and $\mathrm{pH}_{\mathrm{e}}$ showed a negative linear correlation (Fig. 4B).

\section{Gene and protein expression}

In adult mantle muscle, the relative phosphorylation and acetylation on histone $\mathrm{H} 3$ decreased significantly during hypoxia to $74 \%$ of control values while phosphorylation levels alone were unaltered (Fig. 5A). The expression pattern of translation-specific proteins in mantle muscle (Fig. 5B) was different from that in all other tissues (branchial heart, gill and brain) and, as a result, additional targets were measured to further elucidate the muscle-specific response. The phosphorylation state of 4EBP (eukaryotic translation initiation 

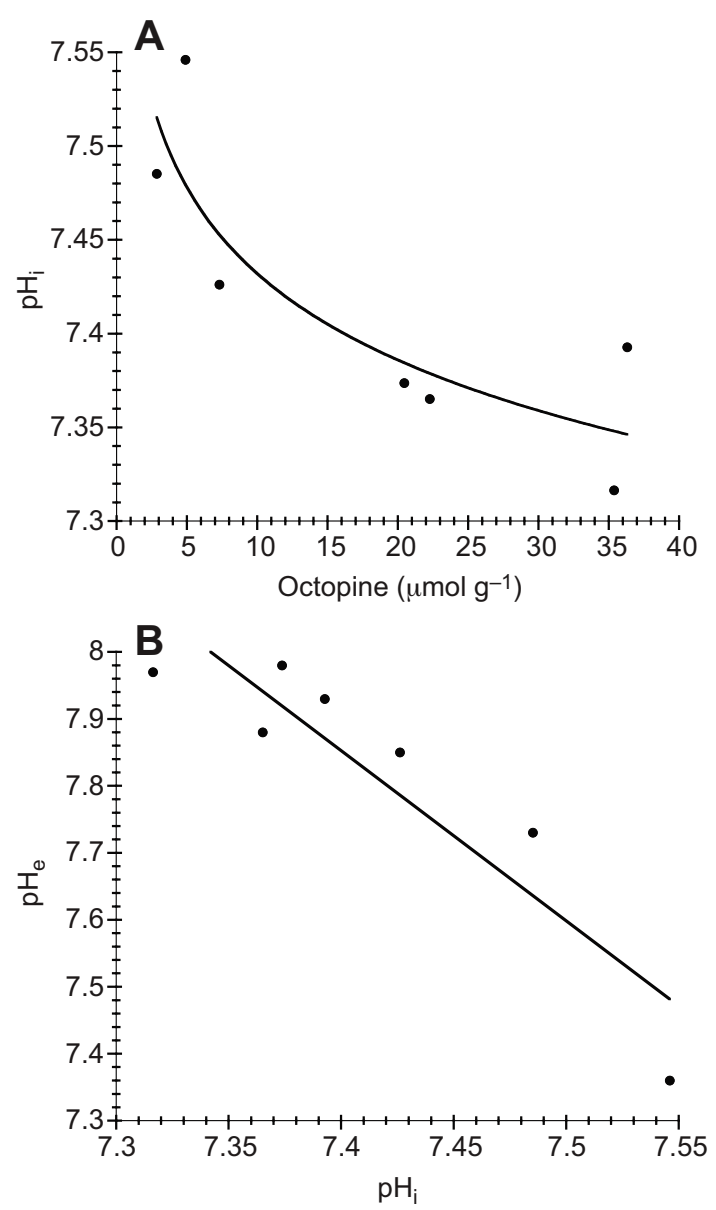

Fig. 4. Intracellular $\mathrm{pH}$ in relation to octopine and extracellular (hemolymph) pH. (A) Intracellular $\mathrm{pH}\left(\mathrm{pH}_{\mathrm{i}}\right)$ is inversely related to octopine $(X)$ concentration $\left(\mathrm{pH}_{\mathrm{i}}=7.6-0.15 \log X\right)$. (B) $\mathrm{pH}_{\mathrm{i}}$ is inversely related to extracellular $\mathrm{pH}\left(\mathrm{pH}_{\mathrm{e}}=27-2.5 \mathrm{pH}_{\mathrm{i}}\right)$.

factor 4E binding protein 1) and HSP27 was significantly enhanced (values in hypoxia were 1.5-fold and 1.3-fold higher than controls, respectively), the phosphorylation state of eEF2 (eukaryotic elongation factor 2) decreased significantly (values in hypoxia were $48 \%$ of controls), and all other targets remained unchanged, including eIF4G (eukaryotic translation initiation factor 4G), eIF2 $\alpha$ (eukaryotic translation initiation factor 2 alpha), eIF4E (eukaryotic translation initiation factor $4 \mathrm{E}$ ) and eEF2K (eukaryotic elongation factor 2 kinase).

In branchial heart, the relative phosphorylation and acetylation on histone $\mathrm{H} 3$ during hypoxia was $50 \%$ of control values while relative changes of the phosphorylation state alone were unaltered (Fig. 6A). With respect to the translation-related targets; a strong decrease in 4EBP was observed (values in hypoxia were $21 \%$ of controls) and all other targets remained unchanged (Fig. 6B). In the brain, the phosphorylation of histone $\mathrm{H} 3$ and 4EBP decreased significantly (values in hypoxia were $58 \%$ and $56 \%$ of controls, respectively), the phosphorylation state of HSP27 had the opposing pattern showing an increase during hypoxia (2-fold higher than controls), and all other targets remained unchanged (Fig. 7A,B). In the gill, posttranslational modifications on histone $\mathrm{H} 3$ decreased to $62 \%$ (phospho) and 60\% (phospho/acetyl) of control values (Fig. 8A). A decrease in the phosphorylation of 4EBP was also seen; however, this was the only translation-related target to change significantly (41\% of control values, Fig. $8 B$ ).

\section{Molecular indices of the stress response}

Compared with control values, the antioxidant capacity in adults was $55 \%, 54 \%$ and $55 \%$ lower in muscle, heart, and brain during hypoxia, respectively (Fig. 9). The relative expression levels of HSP proteins were assessed by immunoblotting in D. gigas muscle comparing control and hypoxic conditions. Fig. 10 shows a significant decrease in the relative expression of HSP25, HSP40 and HSP60 during hypoxia (values in hypoxia were $46 \%, 75 \%$ and $62 \%$ of control values, respectively) while all other targets remained unchanged. Other targets included: GSH (glutathione) and GTP.

\section{DISCUSSION}

The vertical and horizontal distribution of $D$. gigas is closely associated with the OMZ in the Eastern Pacific (Gilly et al., 2006; Rosa and Seibel, 2010). In the Gulf of California, the species spends night-time hours feeding actively in the upper water column (50-150 m) (Benoit-Bird et al., 2012) where $P_{\mathrm{O}_{2}}$ varies with depth but does not reach critical levels $\left(P_{\text {crit }}=1.6 \mathrm{kPa}, 10^{\circ} \mathrm{C}\right.$ ) (Trueblood and Seibel, 2013). During the daytime, however, D. gigas migrates below $200 \mathrm{~m}$, where $P_{\mathrm{O}_{2}}$ is often below $P_{\text {crit }}$. Our results shed light on the rate of energy usage, and on the ultimate metabolic sources and sinks of that energy, at these deeper, severely hypoxic depths. We reveal a substantial suppression of total metabolism that provides an advantage over similarly active predators. The high affinity respiratory protein in the blood facilitates some continued oxygen extraction from hypoxic waters (Seibel, 2013), which accounts for $20 \%$ and $50 \%$ of the total metabolism in the adult and juvenile squid, respectively, at subcritical oxygen levels (Fig. 3). The capacity for metabolic suppression is key to survival in the OMZ. Most active squids (Loliginids and Ommastrephids) show relatively little capacity for hypoxia tolerance (Wells, 1990; Bridges, 1994; Finke et al., 1996). However, the ommastrephid Sthenoteuthis in the Arabian Sea and Gonatus onyx in the California Current also migrate daily into OMZs and likely have similar physiological strategies to those shown here (Shulman et al., 2002; Hunt and Seibel, 2000).

\section{Oxygen consumption and transport}

Normoxic $\dot{M}_{\mathrm{O}_{2}}$ in D. gigas was near $10 \mu \mathrm{mol} \mathrm{O}_{2} \mathrm{~g}^{-1} \mathrm{~h}^{-1}\left(10^{\circ} \mathrm{C}\right)$, among the highest of any marine animal (Seibel and Drazen, 2007). Moreover, because of the shallow scaling slope $[b=0.11$ (Seibel, 2007)] (Fig. 1) relative to fishes [for example, $b=0.21$ (Clarke and Johnston, 1999)], the difference in the rate of metabolism between squids and fishes is especially pronounced at larger sizes. We found that, in agreement with previous studies (Rosa and Seibel, 2010), aerobic metabolism is substantially reduced ( $\sim 85 \%$ and $75 \%$ in adults and juveniles, respectively) at oxygen levels below the $P_{\text {crit }}$ (Fig. 1) in both juvenile and adult squid across six orders of magnitude size range.

\section{$\mathbf{p H}_{\mathbf{e}}$ and oxygen provision in hypoxia}

During exposure to hypoxia, we found that an alkalosis $(\Delta \mathrm{pH} \approx 0.5)$ developed in the blood. Conventional knowledge would suggest that this rise in $\mathrm{pH}_{\mathrm{e}}$ might be caused by a rise in ventilation and also by proton exchange with the hemocyanin. Hypoxia has been shown to induce hyperventilation in the cuttlefish Sepia officinalis (Johansen et al., 1982) and a similar rise in blood $\mathrm{pH}$ has been observed in other cephalopods under conditions of insufficient oxygen supply (Houlihan et al., 1982; Johansen et al., 1982; Pörtner et al., 1990; Pörtner et al., 1991; Pörtner et al., 1993). However, ventilation and locomotion are directly coupled in squids (Wells, 1990). Therefore, hyperventilation would also strongly increase energy costs in $D$. gigas and make it counter-productive in the OMZ. Furthermore, the 

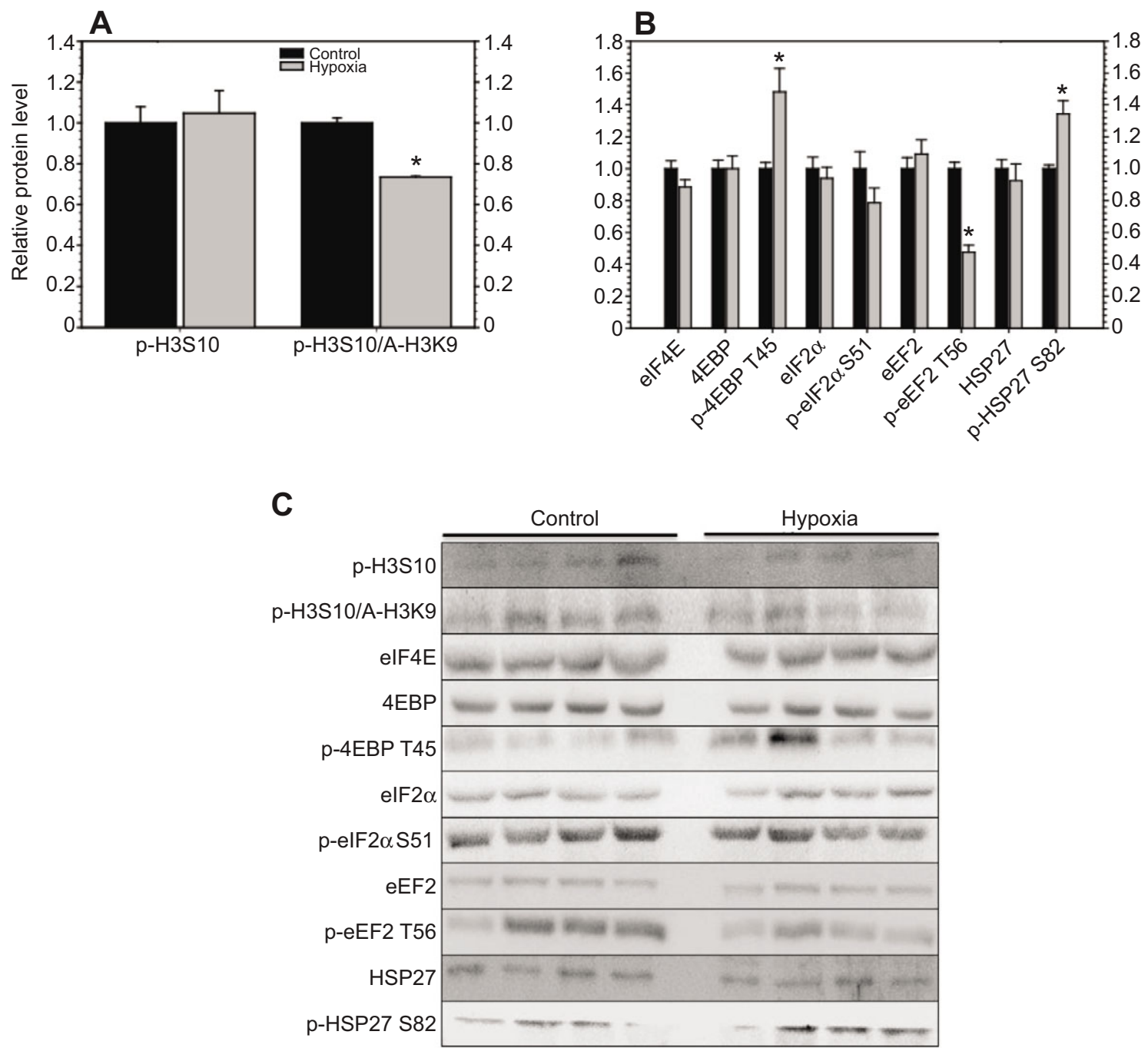

Fig. 5. Changes in mantle muscle protein levels during hypoxic exposure. Levels of p-H3S10, p-H3S10/A-H3K9, elF4E, 4EBP (and phospho T45), elF2 $\alpha$ (and phospho S51), eEF2 (and phospho T56) and HSP27 (and phospho S82) during control and hypoxia in D. gigas are shown. (A) Levels of transcriptionrelated proteins p-H3S10 and p-H3S10/A-H3K9. (B) Levels of translation-related proteins p-4EBP T45, p-elF2 $\alpha$ S51, p-eEF2 T56 and p-Hsp27 S82.

(C) Representative western blots. Histograms show mean normalized band densities ( \pm s.e.m., $N=5$ independent trials on tissue from different animals). Data were analyzed using Student's $t$-test; asterisks denote values are significantly different from controls, $P<0.05$

$\mathrm{OMZ}$ is characterized by elevated $\mathrm{CO}_{2}$ and low $\mathrm{pH}$, further diminishing the utility of hyperventilation to reduce $\mathrm{pH}_{\mathrm{e}}$ (note that under natural conditions, where hypercapnia in the OMZ counteracts the alkalosis, the change in $\mathrm{pH}_{\mathrm{e}}$ could be smaller than that observed here under $\mathrm{CO}_{2}$-free conditions). In fact, a dramatic reduction of the ventilation rate during hypoxia was found in juveniles during hypoxic exposure (Trübenbach et al., 2012a), which is correlated to the metabolic depression. The alkalosis occurs at the expense of $\mathrm{pH}_{\mathrm{i}}$ (Fig. 4) and likely derives from $\mathrm{HCO}_{3}{ }^{-}$transported from the tissue into the blood (Pörtner et al., 1991).

The blood alkalosis observed would increase the affinity of hemocyanin for oxygen, enhancing the oxygen-carrying capacity of the blood in hypoxic waters. At $10^{\circ} \mathrm{C}$, a blood $\mathrm{pH}$ of 7.9 would provide a $P_{50}\left(P_{\mathrm{O}_{2}}\right.$ resulting in $50 \%$ hemocyanin $\mathrm{O}_{2}$ saturation) of $0.4 \mathrm{kPa}$, about half the $P_{\mathrm{O}_{2}}$ achieved during the current experiments and approaching the lowest $P_{\mathrm{O}_{2}}$ experienced in the Gulf of California (Seibel, 2013). Assuming the blood pH was also 7.9 by the end of the closed-respirometry experiments of Trueblood and Seibel (Trueblood and Seibel, 2013), the critical $P_{\mathrm{O}_{2}}$ during resting metabolism $\left(1.6 \mathrm{kPa}\right.$ or $2 \%$ oxygen) was reached at a blood $\mathrm{O}_{2}$ saturation of $\sim 80 \%$ (cf. Seibel, 2013). However, those experiments were carried out in closed chambers starting with air-saturated water such that $\mathrm{CO}_{2}$ concentrations would have been elevated. Oxygen saturation was likely near $60 \%$ at $P_{\text {crit }}$. Oxygen availability to the tissues under more extreme hypoxia must be dependent primarily on the low tissue $P_{\mathrm{O}_{2}}$, in conjunction with the high cooperativity of oxygen binding, that facilitates oxygen off-loading.

A comparative view of findings in Illex illecebrosus, Loligo pealei and $D$. gigas indicates that the $P_{50}$ is highly tuned to the active mode of life in muscular squid, in relation to the modulation of $\mathrm{pH}_{\mathrm{e}}$ and ambient conditions (Redfield and Goodkind, 1929; Pörtner, 1990; Pörtner, 1995; Seibel, 2013). In other words, blood $\mathrm{O}_{2}$ transport sets the whole-animal $P_{\text {crit }}$ in squids and the $P_{\text {crit }}$ is highly dependent on $\mathrm{pH}_{\mathrm{e}}$. Low $P_{50}$ values are required to maintain oxygen-carrying capacity from hypoxic waters just above the OMZ and oxygen release to the tissues is made possible by tight control of $\mathrm{pH}_{\mathrm{e}}$.

\section{Anaerobic energy production}

The rate of anaerobic metabolism was approximately constant for the duration of the hypoxic exposure (Fig. 3), but the anaerobic 



Fig. 6. Changes in branchial heart protein levels during hypoxic exposure. Levels of p-H3S10, p-H3S10/A-H3K9, p-4EBP T45, p-elF2a S51, p-eEF2 T56 and p-Hsp27 S82 during control and hypoxia in $D$. gigas are shown. (A) Levels of transcription-related proteins p-H3S10 and p-H3S10/A-H3K9. (B) Levels of translation-related proteins p-4EBP T45, p-elF2 $\alpha$ S51, p-eEF2 T56 and p-Hsp27 S82. (C) Representative western blots. Other information as in Fig. 5.

sources of ATP varied with the duration of hypoxic exposure. While the absolute values of ATP provided by anaerobic metabolism varied between juveniles and adults, the relative changes during the experiment were similar. Within the first $90 \mathrm{~min}$, the phosphagen (Arg-P) and ATP stores were diminished to about $30 \%$ of their initial values. These metabolites reached a new steady state that was maintained during continuing hypoxia. The decrease in Arg-P was mirrored by an increase in free arginine after the first hour of exposure to hypoxia. However, arginine dropped steadily during the remainder of the experiment, presumably as it was used in the formation of octopine (Fig. 2). The preferred end-product of glycolysis is pyruvate, which reacts with arginine, forming octopine (Grieshaber et al., 1994). This delayed onset of octopine formation is consistent with the findings of Kreutzer et al. (Kreutzer et al., 1989) that opine formation operates near equilibrium and that during hypoxia, opines accumulate according to the concentration of their amino acid precursors. As arginine accumulated, octopine formation was facilitated.

Upregulated glycolysis and accumulation of octopine supplement energy demand following the first hour of hypoxic exposure (Fig. 2C). Glycogen appeared to be the main biochemical substrate during the hypoxic exposure, consistent with previous studies on marine animals (Blazka, 1960; Hochachka and Somero, 1984; Grieshaber et al., 1994). In hypoxia-tolerant organisms, glycogen fermentation is coupled to the transamination of free amino acids (Laspartate and L-glutamate) by generating succinate and ATP (via malate and fumarate synthesis). Succinate can also be directly produced during sustained severe hypoxia under progressive acidosis at the phosphoenolpyruvate branchpoint (via direct conversion from phosphoenolpyruvate to oxaloacetate instead of pyruvate), as this pathway elevates ATP production $(2.5 \mathrm{~mol}$ ATP mol $^{-1}$ L-aspartate/succinate) (Grieshaber et al., 1994). Under low $P_{\mathrm{O}_{2}}$, the respiratory chain will become oxygen limited and succinate accumulates. Thus, succinate is an indicator of the onset of an anaerobic metabolism within the mitochondria (Grieshaber et al., 1994). Succinate, in our study, significantly increased following the first hour of hypoxia exposure (Fig. 2D), but contributed only minimally to total ATP production (Table 1). This may indicate that some fraction of mitochondria remained aerobic, in line with sustained, low levels of aerobic metabolism and hemocyanin functioning.

\section{Metabolic suppression}

We demonstrate a $52 \%$ and $35 \%$ suppression of total ATP demand under hypoxic conditions in juvenile and adult squid, respectively (Table 1). Approximately $50 \%$ of the suppressed energy demand is met aerobically in juveniles compared with only about $30 \%$ in adults. This apparent difference between juveniles and adults may reflect subtle allometric differences in oxygen demand (Fig. 1) (Seibel, 2007) or limitations on glycolytic ATP production at small size (cf. Childress and Somero, 1990). Regardless, reduced ATP consumption serves to protect energy status and fuel stores, and to minimize the accumulation of acidic intermediates of anaerobic ATP-generating pathways during prolonged, diel forays into the OMZ.

Metabolic suppression is typically achieved by shutting down expensive cellular activities including biosynthetic pathways and ion pumping (Hand, 1998; Buck and Hochachka, 1993; Lutz and Nilsson, 1997; Brooks and Storey, 1997). For example, protein synthesis and gene transcription are energy-expensive processes, consuming a substantial portion of the total ATP turnover of all cells and organs (Hochachka and McClelland, 1997). As a result, regulatory mechanisms that suppress cellular gene/protein expression ensure that reductions in ATP supply are matched with 

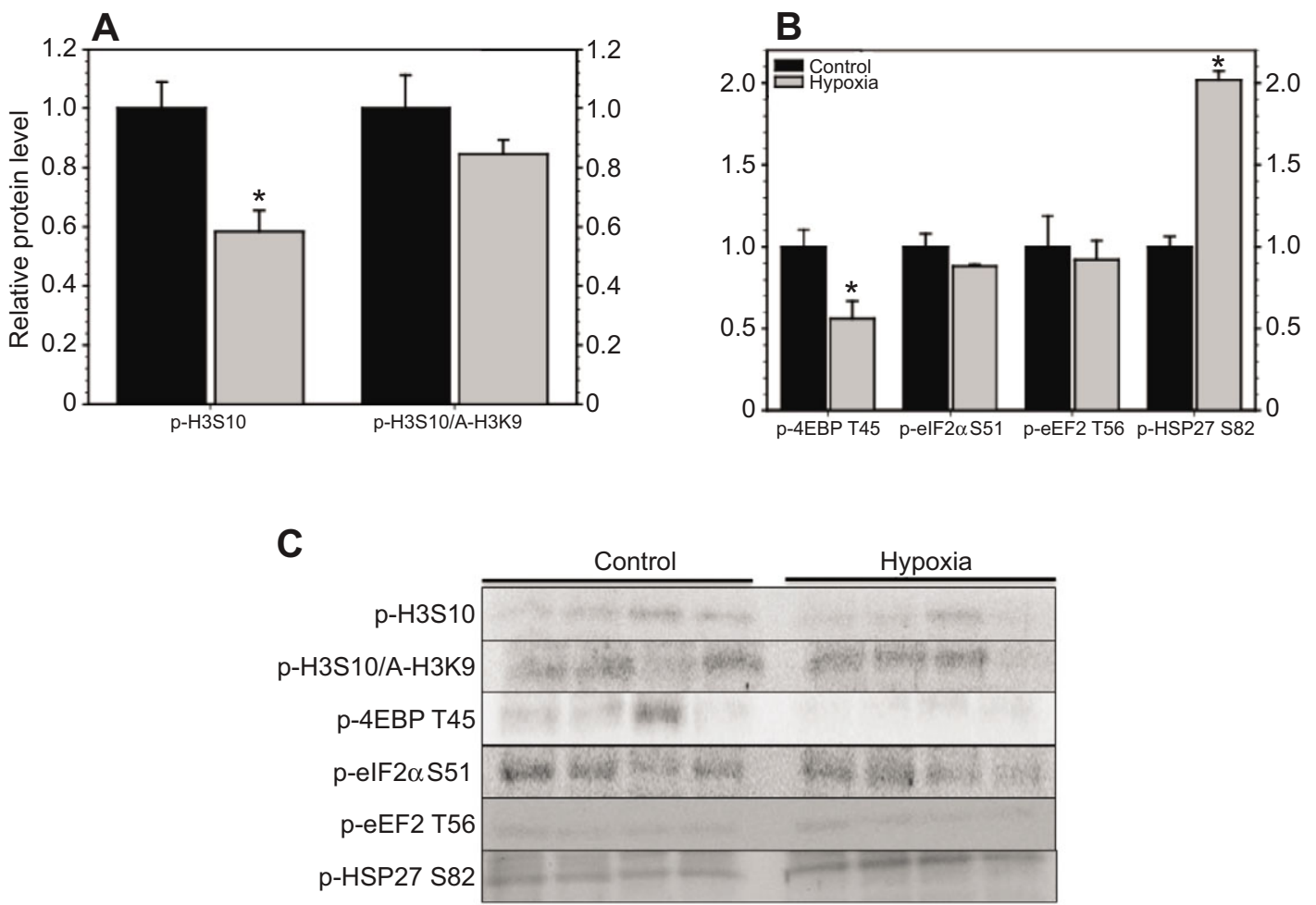

Fig. 7. Changes in brain protein levels during hypoxic exposure. Levels of $p-H 3 S 10, p-H 3 S 10 / A-H 3 K 9, p-4 E B P$ T45, p-eIF2a S51, p-eEF2 T56 and p-Hsp27 S82 during control and hypoxia in D. gigas are shown. (A) Levels of transcription-related proteins p-H3S10 and p-H3S10/A-H3K9. (B) Levels of translation-related proteins p-4EBP T45, p-elF2 $\alpha$ S51, p-eEF2 T56 and p-Hsp27 S82. (C) Representative western blots. Other information as in Fig. 5.

reduced ATP demand (Frerichs et al., 1998; Morin and Storey, 2006; Krivoruchko and Storey, 2010b). In this capacity, ATP concentrations are homeostatic in those species that must survive extended bouts of energy limitation (Nilsson and Lutz, 2004). Turtles and carp that tolerate complete anoxia in frozen ponds over winter maintain ATP concentrations at control levels for several months (Nilsson and Lutz, 2004). Similarly, bivalves maintain ATP concentrations for weeks when exposed to air during low tide (De Zwaan et al., 1991; De Zwaan, 1991). ATP levels fell to a new steady-state level in the present study. In contrast, ATP levels fall to zero within minutes in the absence of oxygen in mammalian systems (Nilsson and Lutz, 2004).

We demonstrated that, similar to other hypometabolic organisms, the jumbo squid exhibits mechanisms that act to globally inhibit transcription and translation, likely resulting in substantial energy savings during hypoxia. At the transcriptional level, all tissues in the present study displayed evidence of chromatin condensation, suggesting a lower rate of transcription during hypoxic conditions (Figs 5-8). Lysine acetylation neutralizes the positive charge normally present on histone tails, thereby reducing affinity with the negatively charged DNA backbone. Consequently, decreases in posttranslational modifications on histone tails observed in the present study during hypoxia would result in condensation of DNA:histone interactions, rendering DNA less accessible to transcription factors (Strahl and Allis, 2000). Phosphorylation of the Ser10 residue on histone $\mathrm{H} 3$ is also involved in chromosome condensation and its close proximity with other modifiable amino acids enables an interaction between other post-translational modifications (Nowak and Corces, 2004). In particular, muscle, heart and gill tissue all demonstrated a relative decrease in multisite post-translational modifications on histone tails. Acetylation of Lys9 (or Lys14) influences Ser10 phosphorylation and this combination could serve to amplify the signal, causing greater changes in overall charge density that lead to greater changes in chromatin structure (Rea et al., 2000; Strahl and Allis, 2000). In muscle tissue in particular, this signal amplification most likely plays a vital role in conserving ATP stores during hypoxia.

Translational suppression is clearly regulated at several checkpoints and this feature allows the organism to fine tune protein synthesis depending on the type of stress and/or tissue-specific needs (Anderson and Kedersha, 2002; Sudhakar et al., 2000; Klann and Dever, 2004). Interestingly, three of the four tissues measured revealed a common mechanism of achieving translational suppression during hypoxic conditions in $D$. gigas. The heart, brain and gills (Figs 6-8) all showed decreases in the phosphorylation state of 4EBP. When phosphorylated, this protein releases its inhibitory interaction with initiation factors, thus enhancing translation (Gingras et al., 1999). Indeed, 4EBP accumulates in hypoxic cells (Hidalgo et al., 2012) and its upstream regulatory kinase is inhibited through multiple pathways during hypoxia (Wouters and Koritzinsky, 2008). Additionally, the brain showed an increase in the phosphorylation state of HSP27, which may stabilize mRNA (Knapinska et al., 2011) and inhibit translation (Cuesta et al., 2000). The observed changes in the phospho-state of these proteins may be sufficient to markedly lower the rates of protein synthesis in these three tissues.

With respect to translation-specific components, the mantle muscle showed a unique expression pattern that was distinct from that of the other tissues observed (Fig. 5). The total protein levels of all translation initiation/elongation targets measured, including 4EBP, remained unchanged. There may be advantages to maintaining basal levels of select translation-specific components in 



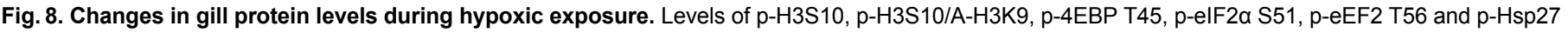
S82 during control and hypoxia in D. gigas are shown. (A) Levels of transcription-related proteins p-H3S10 and p-H3S10/A-H3K9. (B) Levels of translationrelated proteins p-4EBP T45, p-elF2 $\alpha$ S51, p-eEF2 T56 and p-Hsp27 S82. (C) Representative western blots. Other information as in Fig. 5.

muscle during hypoxia as, upon return to relatively oxygenated shallower environments, jumbo squid must escape from predators and actively forage. Additionally, the relative phosphorylation levels of 4EBP increased in muscle during hypoxia and the phosphorylation of eEF2 was significantly decreased. It is quite possible that either HSP27-dependent inhibition of protein synthesis or other mechanisms not identified here also contribute to translational suppression. In summary, hypoxic mantle muscle most likely achieves substantial energy saving by reducing the rate of



Fig. 9. Antioxidant capacity in mantle muscle, branchial heart and brain of $\boldsymbol{D}$. gigas during control and hypoxia. Antioxidants measured in the assay include glutathione (GSH), ascorbate, vitamin $\mathrm{E}$, bilirubin and urate. Data are presented as equivalents of Trolox (means \pm s.e.m., $N=5$ independent trials on tissue from different animals). Data were analyzed using Student's $t$-test; asterisks denote values are significantly different from controls, $P<0.05$. transcription, yet components of the translational apparatus exhibit non-canonical regulatory mechanisms requiring further studies.

Many organisms that transition through states of reduced metabolic rate exhibit alterations in their cellular detoxification and cytoprotective pathways as a means of viability extension (Storey, 1996; Storey and Storey, 2011). In D. gigas, the antioxidant capacity decreased significantly in three tissues (mantle muscle, branchial heart and brain). These data suggest that antioxidant defense strategies may be more important during re-entry into oxygen-rich environments. This hypothesis is supported by data on juvenile squids showing upregulation of antioxidant enzymes during reoxygenation following hypoxic treatment [e.g. catalase, superoxide dismutase, glutathione- $S$-transferase and glutathione peroxidase (Trübenbach et al., 2012b)]. Except for p-HSP27, all other HSPs studied in muscle either decreased significantly (HSP25, HSP40 and HSP60) or remained unaltered (HSP47 and HSP79). While it is possible that simply maintaining basal expression levels is sufficient for effective cytoprotection, further studies are needed elucidate pathways that contribute to cellular survival during hypoxia.

\section{Ecological implications}

Dosidicus gigas' migration in the Gulf of California is closely matched to that of its primary prey, myctophid fishes (Markaida and Sosa-Nishizaki, 2003; Markaida et al., 2008). Furthermore, its expansion into the California Current was coincident with reductions of hake and groundfish populations (Zeidberg and Robison, 2007). These observations have led some to speculate that vertical and horizontal movements facilitate continuous feeding, day and night, in support of high rates of growth and activity (Gilly et al., 2012). However, metabolic suppression and the inefficiency of the 


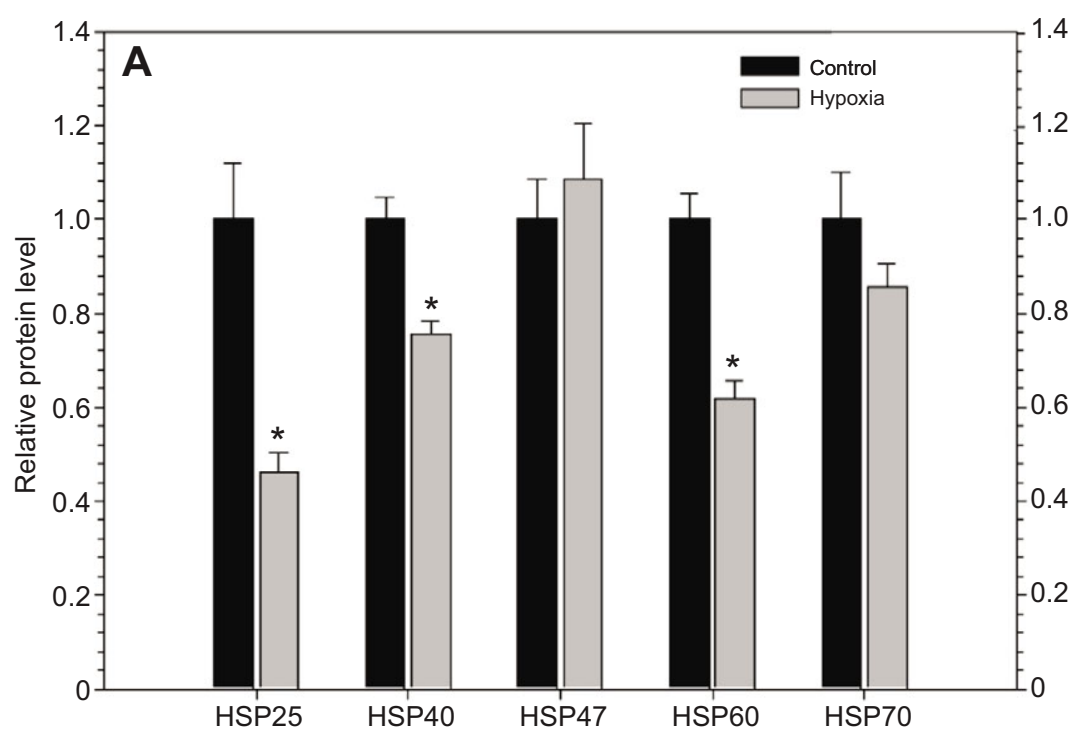

Fig. 10. Changes in the protein levels of HSP25, HSP40, HSP47, HSP60 and HSP70 during control and hypoxia in mantle muscle of $\boldsymbol{D}$. gigas. (A) Levels of stress-responsive HSP proteins. (B) Representative western blots. Other information as in Fig. 5.
B

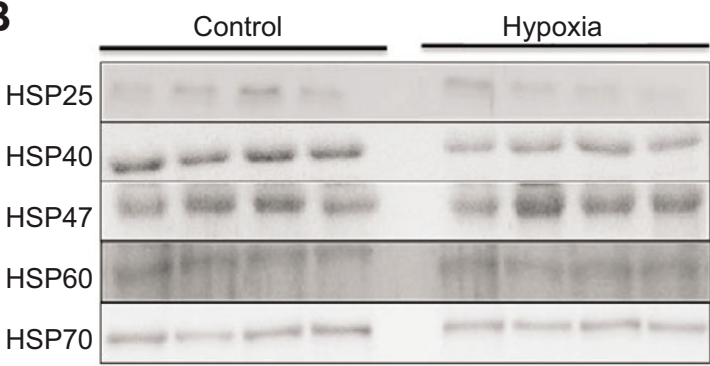

anaerobic pathways that partially offset the ATP deficit would presumably preclude active feeding at the deeper end of its diel migration into the OMZ. Anoxia-tolerant turtles depress metabolism in brain tissue to such an extent that they are nearly comatose (Nilsson, 2001). The fact that brain (and other tissues; Figs 6-8) showed decreases in the phosphorylation state of 4EBP suggests that brain activity may similarly be reduced during daytime. While squids have been seen with remotely operated vehicles (ROVs) attempting to feed within the $\mathrm{OMZ}$, this is likely an unnatural behavior promoted by the lights of the ROV. The feeding was sluggish and often unsuccessful (B.A.S., personal observation). Activity cycles, scope for activity (Rosa and Seibel, 2010), ventilation rates (Trübenbach et al., 2012a) and maximum vertical speeds (Gilly et al., 2012) are all reduced in low oxygen. All of these observations point to a sluggish, non-feeding mode of existence in the OMZ during the daytime.

The depths achieved during the daily migration appear to be somewhat flexible and may be influenced by a number of factors including oxygen, temperature and light levels (Gilly et al., 2012). One tagged individual squid remained at depth continuously for several days (Gilly et al., 2006), although it remained just above its critical $P_{\mathrm{O}_{2}}$ during most of that time period. Other individuals hover near the critical $P_{\mathrm{O}_{2}}$ and move in and out of critical oxygen levels during the daytime. However most individuals spend their entire daytime (up to $\sim 8 \mathrm{~h}$ ) at depths with oxygen levels clearly below their $P_{\text {crit }}$. So while metabolic suppression is not an obligate behavior, it does appear to be an important component of their physiological repertoire. Individuals tagged in the California Current dived somewhat deeper, still achieving depths with $P_{\mathrm{O}_{2}}$ near or below their $P_{\text {crit }}$ (Stewart et al., 2013). This suggests that oxygen, rather than food availability, may dictate their daytime depth. We know that metabolic suppression is triggered by the oxygen itself and not by low temperature or elevated carbon dioxide (Rosa and Seibel, 2008; Rosa and Seibel, 2010). If oxygen has contributed to D. gigas' range expansion into the California Current, it is likely driven by indirect effects on the night-time distributions of prey species into shallower water where the prey, like the squid, must return each night. The prey may be compressed between low oxygen and high temperature into a zone that provides high-density foraging opportunities for these squid (Koslow et al., 2011; Stewart et al., 2014). While D. gigas are extremely flexible predators and may benefit from climate change (Hoving et al., 2013), they may be intolerant of the synergistic effects of either low oxygen or ocean acidification with high temperatures (Rosa and Seibel, 2008; Alegre et al., 2014). All three variables reduce the efficacy of oxygen transport while temperature elevates oxygen demand.

\section{MATERIALS AND METHODS}

\section{Specimen collection}

Juvenile (5.4-13.3 g wet mass) and adult (2-4 kg wet mass) squid were collected using dip-nets and jigs, respectively, in the Gulf of California $\left(27^{\circ} \mathrm{N}, 111^{\circ} \mathrm{W} ; 28^{\circ} \mathrm{N}, 113^{\circ} \mathrm{W}\right)$ on the surface at night, in June 2011 (aboard the R/V New Horizon, Scripps Institute, CA, USA) and were immediately transferred to $10^{\circ} \mathrm{C}$ seawater aquaria on board the vessel.

\section{Experimental procedure}

Animals were placed in flow-through respirometry chambers and allowed to acclimate for $8-12 \mathrm{~h}$ before starting measurements of oxygen 
consumption. Juvenile chambers were immersed in temperature-controlled water baths (Lauda, Lauda-Königshofen, Germany) as described previously (Rosa and Seibel, 2010; Rosa and Seibel, 2008). Adult chambers (transparent $\mathrm{PVC}$, length $130 \mathrm{~cm}$, diameter $16 \mathrm{~cm}$ ) were immersed in a water basin $(180 \times 90 \mathrm{~cm})$ connected to a chiller. For both juveniles and adults, filtered $(0.2 \mu \mathrm{m})$ and treated $\left(50 \mathrm{mg}^{-1}\right.$ streptomycin) seawater was pumped (peristaltic pumps or Mag Drive pump, model WMD-20RLT-115, IWAKI, Tokyo, Japan) from a water-jacketed, gas-equilibration column (multiple columns in the case of the adults) through the respirometers at a constant flow rate $\left(120 \mathrm{ml} \mathrm{min}^{-1}\right.$ for juveniles and $31 \mathrm{~min}^{-1}$ for adults). Following the normoxic acclimation period, the $P_{\mathrm{O}_{2}}$ in the seawater was either maintained (control, 21\% $\mathrm{O}_{2}$ ) or reduced (hypoxic treatment, $1 \% \mathrm{O}_{2}$ ) via equilibration with a certified gas mixture containing $1 \% \mathrm{O}_{2}$, balance nitrogen. These treatments were maintained for up to $3.25 \mathrm{~h}$. Oxygen concentrations were recorded at the entrance and the exit of each chamber with two Clarke-type $\mathrm{O}_{2}$ electrodes connected to a 928 Oxygen Interface (Strathkelvin Instruments, North Lanarkshire, UK). The system was calibrated using airand nitrogen-saturated seawater and checked for electrode drift and for microbial oxygen consumption before and after each trial. All experiments were carried out in darkness and at atmospheric pressure. Afterwards, specimens were weighed on board ship, using a motion-compensated precision shipboard balance system (Childress and Mickel, 1980) for juveniles and hanging spring scales for adults. Tissues (mantle muscle, gill, branchial heart and brain) were excised, wrapped in aluminium foil and frozen in liquid nitrogen until biochemical assays could be performed in the home laboratory.

\section{Metabolite measurements}

In juveniles, anaerobic metabolites (octopine and succinate) and the phosphagen pool (Arg-P) were quantified spectrophotometrically via conversion of $\mathrm{NAD}^{+} / \mathrm{NADH}$ at $339 \mathrm{~nm}$ (Shimadzu, UV-1800) according to standard enzymatic procedures (see Gäde, 1985a; Gäde, 1985b; Beutler, 1989). The method entailed the preparation of perchloric acid $\left(3 \mathrm{~mol}^{-1}\right)$ extracts from frozen mantle tissues and determinations were made immediately after neutralization with $\mathrm{KHCO}_{3}$. The octopine measurement is based on the oxidation of octopine to pyruvate and arginine by octopine dehydrogenase in the presence of $\mathrm{NAD}^{+}$, whereas the increase in $\mathrm{NADH}$ is proportional to the amount of octopine (Gäde, 1985a). Phosphagens were quantified indirectly via arginine after phosphagens (arginine phosphates) had been converted to arginine via acid hydrolysis (Arg$\mathrm{P}=$ - arginine-arginine). Arginine is reductively condensed with pyruvate to octopine by the action of octopine dehydrogenase and the decrease in NADH concentration is proportional to the amount of arginine (Gäde, 1985b). Succinate was quantified via a succinic acid kit (Megazyme, Ireland) according to Beutler (Beutler, 1989). The measurement is based on the conversion of succinate to succinyl-CoA in the presence of ATP and succinyl-CoA synthetase with the concurrent formation of ADP and $\mathrm{P}_{\mathrm{i}}$. ADP reacts with phosphoenolpyruvate (PEP) to form pyruvate and ATP in the presence of pyruvate kinase. The pyruvate produced is reduced to L-lactate by L-lactate dehydrogenase in the presence of NADH by forming NAD ${ }^{+}$. The amount of $\mathrm{NAD}^{+}$formed is stoichiometric with succinate and the decrease in NADH adsorption used to determine succinate.

The extraction of nucleotides was performed according to the procedure of Mendes et al. (Mendes et al., 2001) after some modifications. Nucleotides were extracted by homogenizing $500 \mathrm{mg}$ of muscle with $2.5 \mathrm{ml}$ of $0.6 \mathrm{~mol}^{-1}$ perchloric acid at $0^{\circ} \mathrm{C}$ for $1 \mathrm{~min}$ with a Polytron homogenizer at 20,000 rpm. The homogenate was centrifuged $\left(20,000 \mathrm{~g}, 10 \mathrm{~min}, 0^{\circ} \mathrm{C}\right)$ and $2 \mathrm{ml}$ of the supernatant neutralized to $\mathrm{pH} 6.9$ with $1 \mathrm{moll}^{-1}$ potassium hydroxide solution. The extract was maintained at $0^{\circ} \mathrm{C}$ for $30 \mathrm{~min}$, then potassium perchlorate was removed by filtration using a syringe with a $0.2 \mu \mathrm{m}$ filter. Aliquots were blast frozen $(2 \mathrm{~h})$ in $3 \mathrm{ml}$ vials at $-80^{\circ} \mathrm{C}$ and stored at the same temperature until analysis.

For juvenile squid, adenylate analysis was done with a high performance liquid chromatographic method similar to that reported by Ryder (Ryder, 1985). A Hewlett-Packard 1050 HPLC system and a fixed wavelength detector (MWD HP-1050 Series) set to monitor at $254 \mathrm{~nm}$ were used. Separations were done with a Hewlett-Packard LiChrosorb Reverse Phase18 column $(10 \mathrm{~mm}, 200 \times 4.6 \mathrm{~mm})$ operated isocratically at $30^{\circ} \mathrm{C}$ and
$1.6 \mathrm{ml} \mathrm{min}{ }^{-1}$ with a mobile phase composed of $0.1 \mathrm{moll}^{-1}$ phosphate buffer with a $\mathrm{pH}$ of 6.90. Nucleotides (i.e. ATP standards) were obtained from Sigma.

For adults, adenylates (ATP), phosphagen (Arg-P) and octopine levels were measured using capillary electrophoresis. The prepared perchloric acid extracts of the samples were unfrozen and diluted 1:4. Before analysis by capillary electrophoresis, the samples were filtered and uric acid $\left(2 \mathrm{~g}^{-1}\right.$ mixed 1:10 with sample) was added as an internal standard $\left(\mathrm{P} / \mathrm{ACE}^{\mathrm{TM}}\right.$ System MDQ capillary electrophoresis, Beckmann Coulter GmbH, Krefeld, Germany). The separation was performed using $40 \mathrm{mmol}^{-1}$ borate buffer with additional $10 \mathrm{mmol}^{-1} \mathrm{NaCl}$ for a better resolution of the ATP peak. Initial metabolite concentrations in the mantle tissue ( $\mu \mathrm{mol} \mathrm{g}{ }^{-1}$ wet mass) were calculated considering the dilution during extract preparation.

\section{Total metabolism calculations}

The terms ' $\mathrm{O}_{2}$ consumption' and 'metabolic rate' are often used interchangeably, but the total metabolic rate is actually the combined energy production by aerobic and anaerobic pathways. Aerobic production of energy, in ATP equivalents, is 6 ATP molecules per $\mathrm{O}_{2}$ molecule consumed. Anaerobic production is accounted for by AEE and measured by the increase in the anaerobic end-products octopine and succinate plus the concentration changes in ATP and the phosphagen via the following equation (modified from McDonald et al., 1998):

$$
\mathrm{AEE}=1.5(\Delta \text { octopine })+\Delta \mathrm{ATP}+\Delta \mathrm{Arg}-\mathrm{P}+2.5(\Delta \text { succinate }) .
$$

The term 2.5( $\Delta$ succinate) was added according to Grieshaber et al. (Grieshaber et al., 1994), as anaerobic degradation of $1 \mathrm{~mol}$ of free amino acid L-aspartate results in $1 \mathrm{~mol}$ succinate by generating $2.5 \mathrm{~mol}$ ATP.

\section{Acid-base measurement}

The mantle of adult squid was cut open with a scalpel along the anterior-posterior axis on the ventral side. A blood sample was drawn from the gill artery $\left(\mathrm{O}_{2}\right.$ rich) using sterile $1 \mathrm{ml}$ plastic syringes. The arterial $\mathrm{pH}$ $\left(\mathrm{pH}_{\mathrm{e}}\right)$ of the sample was then measured with a flow-through $\mathrm{pH}$ electrode (Microelectrodes Inc.) and meter (Orion model $720 \mathrm{~A}$ ) at $10^{\circ} \mathrm{C}$. Before measurement, the $\mathrm{pH}$-meter was calibrated with NBS $\mathrm{pH}$ standards of $\mathrm{pH} 7.00$ and $\mathrm{pH} 10.00$, respectively.

$\mathrm{pH}_{\mathrm{i}}$ and tissue $\mathrm{CO}_{2}$ concentration were measured in adult mantle tissue using the homogenate method described previously (Pörtner et al., 1990). To avoid changes in $\mathrm{pH}$ during measurement, potassium fluoride (KF) and nitrilotriacetic acid (NTA) were added to remove $\mathrm{Mg}^{2+}$ and $\mathrm{Ca}^{2+}$ ions. These ions are essential for the activity of kinases and ATPases. As the cellular $\mathrm{H}^{+}$ concentration is almost exclusively affected by ATP-dependent metabolism, the inhibition of the involved enzymes conserves $\mathrm{pH}_{\mathrm{i}}$. Medium parameters were adopted from the ommastrephid squid I. illecebrosus used by Pörtner et al. (Pörtner et al., 1990) (0.16 $\mathrm{mol}^{-1} \mathrm{KF}, 2.9 \mathrm{mmol}^{-1} \mathrm{NTA}$ ).

Briefly, the tissue (200-250 g) was ground to fine powder under liquid nitrogen and mixed with KF/NTA medium. The mixture was homogenized at $0^{\circ} \mathrm{C}$ for $1 \mathrm{~min}$ with an ultrasound rod (Branson Sonifier 450, Hielscher Ultrasound $\mathrm{GmbH}$, Teltow, Germany) and centrifuged at $10,000 \mathrm{~g}$ for $1 \mathrm{~min}$. Optical $\mathrm{pH}_{\mathrm{i}}$ determination in the supernatant was done with a fiberglass optode (PreSens Needle-Type-Housing-pH-Microsensor, PreSens GmbH, Regensburg, Germany) at incubation temperature $\left(10^{\circ} \mathrm{C}\right)$. The optode was calibrated beforehand with NBS $\mathrm{pH}$ standards of elevated ionic strength $\left(I=0.16 \mathrm{~mol} \mathrm{l}^{-1}\right)$ reflecting tissue conditions and a pH-meter $(\mathrm{pH} 3310$, WTW $\mathrm{GmbH}$, Weilheim, Germany). The $\mathrm{pH}$-meter itself was calibrated with NBS $\mathrm{pH}$ standards $\left(I=0.1 \mathrm{mmoll}^{-1}, \mathrm{pH} 6.923\right.$ and 7.472 at $\left.10^{\circ} \mathrm{C}\right)$.

After the $\mathrm{pH}_{\mathrm{i}}$ measurement, $50 \mu \mathrm{l}$ of supernatant was drawn with a gas-

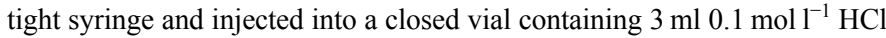
for release of $\mathrm{CO}_{2} . \mathrm{CO}_{2}$ measurements were made via gas chromatograph (6890N Network GC System, Agilent Technologies GmbH, Böblingen, Germany). From the measured $\mathrm{CO}_{2}$ concentration in the supernatant, the tissue $\mathrm{C}_{\mathrm{CO}_{2}}$ and $P_{\mathrm{CO}_{2}}$ were calculated as described previously (Pörtner et al., 1990). $\mathrm{pK}^{\prime \prime \prime}$ and $\alpha_{\mathrm{CO}_{2}}$ were derived from the equations of Heisler (Heisler, 1986) using the values applied by Pörtner et al. (Pörtner et al., 1990). For I. illecebrosus mantle tissue $\left(I=0.16 \mathrm{moll}^{-1}, \quad\left[\mathrm{Na}^{+}\right]=0.015 \mathrm{~mol} \mathrm{l}^{-1}\right.$, 
[protein] $=200 \mathrm{~g} \mathrm{l}^{-1}, 0.560 \mathrm{~mol}^{-1}$ ). These values were derived from intracellular ion measurements by Robertson (Robertson, 1965).

\section{Protein expression, glycogen content and antioxidant capacity Homogenate preparation and protein extraction}

Samples of frozen tissues (mantle muscle, branchial heart, brain and gill) from two sampling points (control and hypoxia) were separately extracted ( $N=4$ samples from different animals). Tissues were quickly weighed, crushed into small pieces under liquid nitrogen, and then homogenized 1:4 w:v using a Polytron PT10. Homogenization was performed in ice-cold homogenizing buffer $\left(20 \mathrm{mmol}^{-1}\right.$ Hepes, $200 \mathrm{mmol}^{-1} \mathrm{NaCl}, 0.1 \mathrm{mmol} \mathrm{l}^{-1}$ EDTA, $10 \mathrm{mmol}^{-1} \mathrm{NaF}, 1 \mathrm{mmol} \mathrm{l}^{-1} \mathrm{Na}_{3} \mathrm{VO}_{4}, 10 \mathrm{mmol} \mathrm{l}^{-1} \beta$-glycerophosphate) with $1 \mathrm{mmol}^{-1}$ phenylmethylsulfonyl fluoride (BioShop) and $1 \mu \mathrm{l}$ protease inhibitor cocktail (BioShop) added immediately before homogenization. Each sample was centrifuged for $10 \min \left(12,000 \mathrm{~g}, 4^{\circ} \mathrm{C}\right)$ and the supernatant was removed. Samples were prepared for western blotting used the Coomassie Blue dye-binding method (Bio-Rad Laboratories, Hercules, CA, USA) using an MR5000 microplate reader to determine protein concentration. Samples were adjusted to a constant $10 \mu \mathrm{g} \mu \mathrm{l}^{-1}$ by addition of small amounts of homogenizing buffer and then aliquots were combined 1:1 v:v with $2 \times$ SDS loading buffer (100 $\mathrm{mmol}^{-1}$ Tris-base $\mathrm{pH} 6.8,4 \%$ w:v SDS, $20 \%$ v:v glycerol, 0.2\% w:v Bromophenol Blue, 10\% v:v 2-mercaptoethanol) and boiled for $5 \mathrm{~min}$. Final protein samples $\left(5 \mu \mathrm{g} \mu \mathrm{l}^{-1}\right)$ were stored at $-40^{\circ} \mathrm{C}$ until use.

\section{Western blotting}

The relative expression levels of proteins that are involved in modulating the rate of transcription (histone $\mathrm{H} 3$ ) and translation (4EBP, eIF2, eIF4E, eEF2, HSP27) were assessed by immunoblotting in four tissues (muscle, heart, brain and gill), comparing control and hypoxic sampling points of D. gigas (Figs 5-7). Post-translational modifications of these targets are indicative of rates of transcription and translation; phosphorylation/ acetylation of histones at Ser10/Lys9 and phosphorylation of 4EBP at Thr45 result in enhanced transcription and translation, respectively (Strahl and Allis, 2000; Gingras et al., 1999). In contrast, phosphorylation of eIF2 at Ser51 (Sudhakar et al., 2000), eEF2 at Thr56 (Hizli et al., 2013) and HSP27 at Ser82 (Cuesta et al., 2000) is correlated with translational suppression.

Equal amounts of protein from each sample were loaded onto $8-12 \%$ SDS-polyacrylamide gels and run at $180 \mathrm{~V}$ for $45 \mathrm{~min}$ in $1 \times$ Tris-glycine SDS running buffer [as described previously (Zhang and Storey, 2012)]. Proteins were then transferred by electroblotting at $160 \mathrm{~mA}$ using transfer buffer $\left(25 \mathrm{mmol}^{-1}\right.$ Tris $\mathrm{pH} 8.5,192 \mathrm{mmol}^{-1}$ glycine and $10 \% \mathrm{v} / \mathrm{v}$ methanol) at room temperature. For targets $<25 \mathrm{kDa}$ we used $0.2 \mu \mathrm{m}$ PVDF membranes and transferred for $1 \mathrm{~h}$, while for targets $>25 \mathrm{kDa}$ we used $0.45 \mu \mathrm{m}$ PVDF membranes and transferred for $1.5 \mathrm{~h}$. Membranes were blocked with milk $(2.5 \% \mathrm{w}: \mathrm{v})$ made up in TBST $\left(20 \mathrm{mmol}^{-1}\right.$ Tris base $\mathrm{pH} 7.6,140 \mathrm{mmol}^{-1} \mathrm{NaCl}, 0.05 \% \mathrm{v} / \mathrm{v}$ Tween-20) on a rocker for $20 \mathrm{~min}$ in order to reduce background and non-specific binding of antibodies. Membranes were probed with specific primary antibodies, diluted in TBST, at $4^{\circ} \mathrm{C}$ overnight. Antibodies were purchased from Cell Signaling (histone H3, eIF4E, 4EBP, eEF2), GenScript (eIF2 $\alpha$, HSP27) or Stressgen (HSP40, HSP47, HSP60, HSP70) and were used at 1:1000 v:v dilution in TBST. Membranes were then probed with either HRP-linked anti-mouse IgG secondary antibody ( 1:4000 v:v dilution) or HRP-linked anti-rabbit IgG secondary antibody ( 1:8000 v:v dilution). All membranes were washed three times between incubation periods in TBST for $\sim 5$ min per wash. Bands were visualized by enhanced chemiluminescence $\left(\mathrm{H}_{2} \mathrm{O}_{2}\right.$ and Luminol) and then blots were restained in Coomassie stain $(0.25 \% \mathrm{w} / \mathrm{v}$ Coomassie Brilliant Blue, $7.5 \% \mathrm{v} / \mathrm{v}$ acetic acid, $50 \%$ methanol) to visualize all protein bands. Antibodies each cross-reacted with strong bands on the immunoblots at the expected molecular masses for histone H3 (17 kDa), eIF4E (25 kDa), 4EBP (19 kDa), eIF2 $\alpha$ (36 kDa), eEF2 (95 kDa), HSP27 (27 kDa), HSP40 (40 kDa), HSP60 (60 kDa) and HSP70 (70 kDa).

\section{Glycogen and antioxidant capacity assay}

The glycogen assay kit was purchased from Cayman Chemical Company (cat. no. 700480, Ann Arbor, MI, USA). As per the manufacturer's directions, samples were homogenized in ice-cold glycogen assay buffer, centrifuged $\left(800 \mathrm{~g}, 10 \mathrm{~min}, 4^{\circ} \mathrm{C}\right)$, the supernatant collected and the gram wet mass recorded for each sample. A vial of lyophilized glycogen was reconstituted in glycogen assay buffer (phosphate-buffered saline containing protease inhibitor, $\mathrm{pH}$ 7.0) to a final concentration of $200 \mu \mathrm{g} \mathrm{ml}^{-1}$ and vortexed. The standard curve combined increasing amounts of the reconstituted glycogen diluted in glycogen assay buffer and used the following concentrations: $0,2.5,5,10,15,20,30$ and $40 \mu \mathrm{g} \mathrm{ml}^{-1}$. The standard wells were prepared by adding $10 \mu \mathrm{l}$ of standard and $50 \mu \mathrm{l}$ of reconstituted hydrolysis enzyme solution (lyophilized powder of amyloglucosidase reconstituted in a $50 \mathrm{mmol}^{-1}$ acetate glycogen hydrolysis buffer, $\mathrm{pH}$ 4.5). The sample wells (muscle only) were prepared by first diluting the stock 1:10 v:v in glycogen assay buffer and adding $10 \mu \mathrm{l}$ of sample per well. The sample background wells were prepared by adding $10 \mu \mathrm{l}$ of the same diluted sample and $50 \mu \mathrm{l}$ of the glycogen hydrolysis buffer (without amyloglucosidase). The plate was covered and incubated for $30 \mathrm{~min}$ at $37^{\circ} \mathrm{C}$ to allow for full glycogen hydrolysis. The developer was prepared by combining the following components: $0.5 \mathrm{ml}$ fluorometric detector (lyophilized powder of 10-acetyl-3,7-dihydroxyphenoxazine, reconstituted in $100 \mu \mathrm{l}$ DMSO and $400 \mu 1$ assay buffer), $2.5 \mathrm{ml}$ enzyme mixture (lyophilized enzyme mixture reconstituted in $2.5 \mathrm{ml}$ assay buffer) and $5 \mathrm{ml}$ assay buffer. Following a $30 \mathrm{~min}$ incubation, $150 \mu \mathrm{l}$ of developer was added to all wells including the standard, sample and sample background wells. The plate was covered, incubated $\left(15 \mathrm{~min}, 37^{\circ} \mathrm{C}\right)$, and then read in a Cary Eclipse Fluorescence Spectrophotometer (Agilent Technologies, Mississauga, ON, Canada). An excitation wavelength of $530-540 \mathrm{~nm}$ and an emission wavelength of $585-595 \mathrm{~nm}$ were used.

The antioxidant capacity was assessed in three tissues (muscle, heart, brain) of D. gigas comparing control and hypoxic experimental conditions (Fig. 9). The capacity of the antioxidants in the sample (e.g. GSH, ascorbate, vitamin $\mathrm{E}$, bilirubin and urate) to prevent ABTS oxidation was compared with that of Trolox and was quantified as $\mathrm{mmol}^{-1}$ Trolox equivalents. The antioxidant assay kit was purchased by Cayman Chemical Company (cat. no. 709001) and the experimental procedure followed the manufacturer's directions. A vial of lyophilized Trolox (6-hydroxy-2,5,7,8-tetramethylchroman-2-carboxylic acid) and Chromogen (ABTS) was reconstituted in HPLC-grade water while metmyoglobin was reconstituted in antioxidant assay buffer $\left(5 \mathrm{mmol} 1^{-1}\right.$ potassium phosphate, $\mathrm{pH} 7.4$, containing $0.9 \%$ sodium chloride and $0.1 \%$ glucose) and vortexed. The standard curve combined increasing amounts of the reconstituted Trolox diluted in assay buffer with the following concentrations; $0,0.045,0.090,0.135,0.18,0.225$ and $0.330 \mathrm{mmol}^{-1}$. The standard wells were prepared by adding $10 \mu \mathrm{l}$ of a Trolox preparation, $10 \mu \mathrm{l}$ of metmyoglobin and $150 \mu \mathrm{l}$ of Chromogen per well. The sample wells were prepared by first diluting the stock 1:10 v:v in assay buffer (muscle, heart and brain) and adding $10 \mu \mathrm{l}$ of sample, $10 \mu \mathrm{l}$ of metmyoglobin and $150 \mu \mathrm{l}$ of chromogen per well. The reactions were initiated by adding $40 \mu \mathrm{l}$ of hydrogen peroxide working solution $\left(441 \mu \mathrm{mol}^{-1}\right)$ and the samples were incubated on a shaker for $5 \mathrm{~min}$ at room temperature. The absorbance was read at $750 \mathrm{~nm}$ using a Multiskan plate reader (Thermo Scientific, Ottawa, ON, Canada). Antioxidants measured in the assay include GSH, ascorbate, vitamin E, bilirubin and urate.

\section{Statistics}

Because metabolism varied with the duration of exposure to hypoxia, all metabolite data are expressed individually as a function of time and analyzed using best fit models. However, glycogen content, antioxidant capacity and immunoblots (see 'Protein expression, glycogen content and antioxidant capacity', above) are expressed as means ( \pm s.e.m.) of pooled data. Significant differences in metabolite concentrations and oxygen consumption rates between hypoxia $\left(0.8 \mathrm{kPa} P_{\mathrm{O}_{2}}\right)$ and normoxia $(21 \mathrm{kPa}$ $P_{\mathrm{O}_{2}}$ ) were assessed using Student's $t$-tests or, for relationships to exposure duration, ANCOVA, and significance was assessed at $P<0.05$. Band densities on chemiluminescent immunoblots were visualized using a ChemiGenius BioImaging system (Syngene, Frederick, MD, USA) and quantified using the associated Gene Tools software. Immunoblot band density in each lane was standardized against the summed intensity of a group of Coomassie-stained protein bands in the same lane; these were chosen because they did not show variation between different experimental states 
and were not located close to the protein bands of interest. Statistical testing of standardized band intensities and antioxidant capacity used Student's $t$ test $(P<0.05)$.

\section{Acknowledgements}

We thank the captain and crew of the R/V New Horizon for assistance at sea. We thank E. McLean, M. Birk, A. Bockus, A. Nyack, T. Towanda and L. Elder for assistance in the lab and field and/or for constructive comments on the manuscript. Timo Hirse provided excellent technical support. We thank Alison Sweeney for providing additional ship time. We thank the Mexican government fo their gracious permission to conduct research in their waters (SAGARPA Permiso de Pesca de Foment No. DAPA/2/130511/01347 and No. DAPA/2/100510/1640 Diplomatic note number issued by SRE DAN-01297).

\section{Competing interests}

The authors declare no competing financial interests.

\section{Author contributions}

This project was conceived by B.A.S., R.R. and K.B.S. Data collection/analysis were carried out as follows: respirometry experiments, B.A.S., R.R. and K.T.; metabolite measurement, K.T., N.S.H., R.R., H.O.P., K.B.S., J.Z. and S.N.T.; acid-base analysis, N.S.H., B.A.S. and H.O.P.; protein expression, K.B.S., J.Z. and S.N.T. The manuscript was written by B.A.S., N.S.H., K.T., K.B.S. and S.N.T. All authors contributed to manuscript revision.

\section{Funding}

This work was funded by National Science Foundation grant no. 0851043 to B.A.S., The Natural Sciences and Engineering Research Council of Canada (NSERC) to K.B.S., Alfred Wegener Institute research program Programme Marine, Coastal and Polar Systems: Polar Regions and Coasts in a changing Earth System (PACES) to H.O.P., and the Portugal-US Research Networks Program (FLAD/US National Science Foundation Research Grant) and The Portuguese Foundation for Science and Technology (FCT, Ciência 2007 Program) to R.R.

\section{References}

Alegre, A., Ménard, F., Tafur, R., Espinoza, P., Argüelles, J., Maehara, V., Flores, O., Simier, M. and Bertrand, A. (2014). Comprehensive model of jumbo squid Dosidicus gigas trophic ecology in the Northern Humboldt current system. PLoS ONE 9, e85919.

Anderson, P. and Kedersha, N. (2002). Stressful initiations. J. Cell Sci. 115, 32273234

Benoit-Bird, K. J. and Gilly, W. F. (2012). Coordinated nocturnal behavior of foraging jumbo squid, Dosidicus gigas. Mar. Ecol. Prog. Ser. 455, 211-228.

Beutler, H.-O. (1989). Succinate. In Methods of Enzymatic Analysis, Vol. VII (ed. H. U. Bergmeyer), pp. 25-33. Cambridge: VCH Publishers (UK) Ltd.

Bickler, P. E. and Buck, L. T. (2007). Hypoxia tolerance in reptiles, amphibians, and fishes: life with variable oxygen availability. Annu. Rev. Physiol. 69, 145-170.

Blazka, P., Volf, M. and Cepela, M. (1960). A new type of respirometer for the determination of metabolism of fish in an active state. Physiol. Bohemoslov. 9, 553559.

Bograd, S. J., Castro, C. G., Di Lorenzo, E., Palacios, D. M., Bailey, H., Gilly, W. and Chavez, F. P. (2008). Oxygen declines and the shoaling of the hypoxic boundary in the California Current. Geophys. Res. Lett. 35, L12607.

Bridges, C. R. (1994). Bohr and Root effects in cephalopod haemocyanins - paradox or pressure in Sepia officinalis? In Physiology of Cephalopod Molluscs: Lifestyle and Performance Adaptations (ed. H. O. Portner, R. K. O'Dor and D. L. MacMillan), pp. 121-130. Philadelphia, PA: Gordon and Breach.

Brill, R. W. (1994). A review of temperature and oxygen tolerance studies of tunas pertinent to fisheries oceanography, movement models and stock assessments. Fish. Oceanogr. 3, 204-216.

Brooks, S. P. and Storey, K. B. (1997). Glycolytic controls in estivation and anoxia: a comparison of metabolic arrest in land and marine molluscs. Comp. Biochem. Physiol. 118A, 1103-1114.

Buck, L. T. and Hochachka, P. W. (1993). Anoxic suppression of $\mathrm{Na}^{+}-\mathrm{K}^{+}-$ATPase and constant membrane potential in hepatocytes: support for channel arrest. Am. J. Physiol. 265, R1020-R1025.

Childress, J. J. and Mickel, T. J. (1980). A motion compensated shipboard precision balance system. Deep Sea Res. Part A. Oceanogr. Res. Papers 27, 965-970.

Childress, J. J. and Somero, G. N. (1990). Metabolic scaling: a new perspective based on scaling of glycolytic enzyme activities. Am. Zool. 30, 161-173.

Clarke, A. and Johnston, N. A. (1999). Scaling of metabolic rate with body mass and temperature in teleost fish. J. Anim. Ecol. 68, 893-905.

Cuesta, R., Laroia, G. and Schneider, R. J. (2000). Chaperone hsp27 inhibits translation during heat shock by binding elF4G and facilitating dissociation of capinitiation complexes. Genes Dev. 14, 1460-1470.

De Zwaan, A. (1991). Molluscs. In Metazoan Life Without Oxygen (ed. C. Bryant), pp. 186-217. London: Chapman and Hall.
De Zwaan, A., Cortesi, P., van der Thillart, G., Roos, J. and Storey, K. B. (1991). Differential sensitivities to hypoxia by two anoxia-tolerant marine molluscs: a biochemical analysis. Mar. Biol. 111, 343-351.

Finke, E., Pörtner, H. O., Lee, P. G. and Webber, D. M. (1996). Squid (Lolliguncula brevis) life in shallow waters: oxygen limitation of metabolism and swimming performance. J. Exp. Biol. 199, 911-921.

Frerichs, K. U., Smith, C. B., Brenner, M., DeGracia, D. J., Krause, G. S., Marrone, L., Dever, T. E. and Hallenbeck, J. M. (1998). Suppression of protein synthesis in brain during hibernation involves inhibition of protein initiation and elongation. Proc. Natl. Acad. Sci. USA 95, 14511-14516.

Gäde, G. (1985a). Octopine. In Methods of Enzymatic Analysis, Vol. IX (ed. H. U. Bergmeyer), pp. 419-424. Cambridge: VCH Publishers (UK) Ltd.

Gäde, G. (1985b). Arginine and arginine phosphate. In Methods of Enzymatic Analysis, Vol. IX (ed. H. U. Bergmeyer), pp. 425-431. Cambridge: VCH Publisher (UK) Ltd.

Gilly, W. F., Markaida, U., Baxter, C. H., Block, B. A., Boustany, A., Zeidberg, L., Reisenbichler, K., Robison, B., Bazzino, G. and Salinas, C. (2006). Vertical and horizontal migrations by the jumbo squid Dosidicus gigas revealed by electronic tagging. Mar. Ecol. Prog. Ser. 324, 1-17.

Gilly, W. F., Zeidberg, L. D., Booth, J. A., Stewart, J. S., Marshall, G., Abernathy, K. and Bell, L. E. (2012). Locomotion and behavior of Humboldt squid, Dosidicus gigas, in relation to natural hypoxia in the Gulf of California, Mexico. J. Exp. Biol. 215, 3175-3190.

Gingras, A. C., Gygi, S. P., Raught, B., Polakiewicz, R. D., Abraham, R. T., Hoekstra, M. F., Aebersold, R. and Sonenberg, N. (1999). Regulation of 4E-BP1 phosphorylation: a novel two-step mechanism. Genes Dev. 13, 1422-1437.

Grieshaber, M. K., Hardewig, I., Kreutzer, U. and Pörtner, H. O. (1994). Physiological and metabolic responses to hypoxia in invertebrates. Rev. Physiol. Biochem. Pharmacol. 125, 43-147.

Guppy, M. and Withers, P. (1999). Metabolic depression in animals: physiological perspectives and biochemical generalizations. Biol. Rev. Camb. Philos. Soc. 74, 140.

Hand, S. C. (1998). Quiescence in Artemia franciscana embryos: reversible arrest of metabolism and gene expression at low oxygen levels. J. Exp. Biol. 201, 1233-1242.

Heisler, N. (1986). Comparative aspects of acid-base regulation. In Acid-Base Regulation in Animals, pp. 397-450. Amsterdam: Elsevier.

Hidalgo, M., Le Bouffant, R., Bello, V., Buisson, N., Cormier, P., Beaudry, M. and Darribère, T. (2012). The translational repressor 4E-BP mediates hypoxia-induced defects in myotome cells. J. Cell Sci. 125, 3989-4000.

Hittel, D. and Storey, K. B. (2002). The translation state of differentially expressed mRNAs in the hibernating 13-lined ground squirrel (Spermophilus tridecemlineatus). Arch. Biochem. Biophys. 401, 244-254.

Hizli, A. A., Chi, Y., Swanger, J., Carter, J. H., Liao, Y., Welcker, M., Ryazanov, A. G. and Clurman, B. E. (2013). Phosphorylation of eukaryotic elongation factor 2 (eEF2) by cyclin A-cyclin-dependent kinase 2 regulates its inhibition by eEF2 kinase. Mol. Cell. Biol. 33, 596-604.

Hochachka, P. W. and McClelland, G. B. (1997). Cellular metabolic homeostasis during large-scale change in ATP turnover rates in muscles. J. Exp. Biol. 200, 381386

Hochachka, P. W. and Somero, G. N. (1984). Biochemical Adaptation. Princeton, NJ: Princeton University Press.

Houlihan, D. F., Innes, A. J., Wells, M. J. and Wells, J. (1982). Oxygen consumption and blood gases of Octopus vulgaris in hypoxic conditions. J. Comp. Physiol. 148, $35-40$

Hoving, H. J., Gilly, W. F., Markaida, U., Benoit-Bird, K. J., -Brown, Z. W., Daniel, P., Field, J. C., Parassenti, L., Liu, B. and Campos, B. (2013). Extreme plasticity in life-history strategy allows a migratory predator (jumbo squid) to cope with a changing climate. Glob. Chang. Biol. 19, 2089-2103.

Hunt, J. C. and Seibel, B. A. (2000). Life history of Gonatus onyx (Cephalopoda: Teuthoidea): ontogenetic changes in habitat, behavior and physiology. Mar. Biol. 136, 543-552.

Jackson, G. D. and Domeier, M. L. (2003). The effects of an extraordinary El Nino/La Nina on the size and growth of the squid, Loligo opalescens off Southern California. Mar. Biol. 142, 925-935

Johansen, K., Brix, O. and Lykkeboe, G. (1982). Blood gas transport in the cephalopod, Sepia officinalis. J. Exp. Biol. 99, 331-338.

Keeling, R. E., Körtzinger, A. and Gruber, N. (2010). Ocean deoxygenation in a warming world. Ann. Rev. Mar. Sci. 2, 199-229.

Klann, E. and Dever, T. E. (2004). Biochemical mechanisms for translational regulation in synaptic plasticity. Nat. Rev. Neurosci. 5, 931-942.

Knapinska, A. M., Gratacós, F. M., Krause, C. D., Hernandez, K., Jensen, A. G., Bradley, J. J., Wu, X., Pestka, S. and Brewer, G. (2011). Chaperone Hsp27 modulates AUF1 proteolysis and AU-rich element-mediated mRNA degradation. Mol. Cell. Biol. 31, 1419-1431.

Koslow, J. A., Goerike, R., Lara-Lopez, A. and Watson, W. (2011). Impact of declining intermediate-water oxygen on deepwater fishes in the California Current. Mar. Ecol. Prog. Ser. 436, 207-218.

Kreutzer, U., Siegmund, B. R. and Grieshaber, M. K. (1989). Parameters controlling opine formation during muscular activity and environmental hypoxia. J. Comp. Physiol. B 159, 617-628.

Krivoruchko, A. and Storey, K. B. (2010a). Regulation of the heat shock response under anoxia in the turtle, Trachemys scripta elegans. J. Comp. Physiol. B 180, 403414

Krivoruchko, A. and Storey, K. B. (2010b). Epigenetics in anoxia tolerance: a role for histone deacetylases. Mol. Cell. Biochem. 342, 151-161. 
Krivoruchko, A. and Storey, K. B. (2010c). Forever young: mechanisms of natural anoxia tolerance and potential links to longevity. Oxid. Med. Cell. Longev. 3, 186198

Larade, K. and Storey, K. B. (2002). Reversible suppression of protein synthesis in concert with polysome disaggregation during anoxia exposure in Littorina littorea. Mol. Cell. Biochem. 232, 121-127.

Lutz, P. L. and Nilsson, G. E. (1997). Contrasting strategies for anoxic brain survival glycolysis up or down. J. Exp. Biol. 200, 411-419.

Markaida, U. and Sosa-Nishizaki, X. X. (2003). Food and feeding habits of jumbo squid, Dosidicus gigas (Cephalopoda: Ommastrephidae), from the Gulf of California, Mexico. J. Mar. Biol. Assoc. UK 83, 507-522.

Markaida, U., Gilly, W. F., Salinas-Zavala, C., Rosas-Luis, R. and Booth, A. (2008). Food and feeding of jumbo squid Dosidicus gigas in the central Gulf of California during 2005-2007. CalCOFI Rep. 49, 90-103.

Matteson, R. S., Benoit-Bird, K. J. and Gilly, W. F. (2009). Humboldt squid distribution in three-dimensional space as measured by acoustics in the Gulf of California. J. Acoust. Soc. Am. 125, 2550.

McDonald, D. G., McFarlane, W. J. and Milligan, C. L. (1998). Anaerobic capacity and swim performance of juvenile salmonids. Can. J. Fish. Aquat. Sci. 55, 1198 1207.

Mendes, R., Quinta, R. and Nunes, M. L. (2001). Changes in baseline levels of nucleotides during ice storage of fish and crustacean from the Portuguese coast. Eur. Food Res. Technol. 212, 141-146.

Morin, P., Jr and Storey, K. B. (2006). Evidence for a reduced transcriptional state during hibernation in ground squirrels. Cryobiology 53, 310-318.

Nasby-Lucas, N., Dewar, H., Lam, C. H., Goldman, K. J. and Domeier, M. L. (2009) White shark offshore habitat: a behavioral and environmental characterization of the eastern Pacific shared offshore foraging area. PLOS ONE 4, e8163.

Nesis, K. N. (1983). Dosidicus gigas In Cephalopod Life Cycles, Species Accounts. London: Academic Press.

Nigmatullin, C. M., Nesis, K. N. and Arkhipkin, A. I. (2001). A review on the biology of the jumbo squid Dosidicus gigas. Fish. Res. 54, 9-19.

Nilsson, G. E. (2001). Surviving anoxia with the brain turned on. News Physiol. Sci. 16, 217-221.

Nilsson, G. E. and Lutz, P. L. (2004). Anoxia tolerant brains. J. Cereb. Blood Flow Metab. 24, 475-486.

Nowak, S. J. and Corces, V. G. (2004). Phosphorylation of histone H3: a balancing act between chromosome condensation and transcriptional activation. Trends Genet. 20, 214-220.

O'Dor, R. K. and Webber, D. M. (1986). The constraints on cephalopods: why squid aren't fish. Can. J. Zool. 64, 1591-1605.

Pörtner, H.-O. (1990). An analysis of the effects of $\mathrm{pH}$ on oxygen binding by squid (Illex illecebrosus, Loligo pealei) haemocyanin. J. Exp. Biol. 150, 407-424.

Pörtner, H.-O. (1995). Coordination of metabolism, acid-base regulation and haemocyanin function in cephalopods. Mar. Freshw. Behav. Physiol. 25, 131-148.

Pörtner, H.-O., Boutilier, R. G., Yang, Y., and Toews, D. P. (1990). Measurement of intracellular $\mathrm{pH}$ and $\mathrm{P}_{\mathrm{CO}_{2}}$ after metabolic inhibition by fluoride and nitrilotracetic acid. Respir. Physiol. 81, 255-274.

Pörtner, H.-O., Webber, D. M., Boutilier, R. G. and O'Dor, R. K. (1991). Acid-base regulation in exercising squid (Illex illecebrosus, Loligo pealei). Am. J. Physiol. 261 R239-R246.

Pörtner, H.-O., Webber, D. M., O'Dor, R. K. and Boutilier, R. G. (1993). Metabolism and energetics in squid (Illex illecebrosus, Loligo pealei) during muscular fatigue and recovery. Am. J. Physiol. 265, R157-R165

Prince, E. D. and Goodyear, C. P. (2006). Hypoxia-based habitat compression of tropical pelagic fishes. Fisheries Oceanography 15, 451-464.

Rea, S., Eisenhaber, F., O'Carroll, D., Strahl, B. D., Sun, Z. W., Schmid, M., Opravil, S., Mechtler, K., Ponting, C. P., Allis, C. D. et al. (2000). Regulation of chromatin structure by site-specific histone H3 methyltransferases. Nature 406, 593599.

Redfield, A. C. and Goodkind, R. (1929). The significance of the Bohr effect in the respiration and asphysixiation of the squid, Loligo pealei. J. Exp. Biol. 6, 340-349.

Robertson, J. D. (1965). Studies on the chemical composition of muscle tissue. III. The mantle muscle of cephalopod molluscs. J. Exp. Biol. 42, 153-175.

Rosa, R. and Seibel, B. A. (2008). Synergistic effects of climate-related variables suggest future physiological impairment in a top oceanic predator. Proc. Natl. Acad. Sci. USA 105, 20776-20780.

Rosa, R. and Seibel, B. A. (2010). Metabolic physiology of the Humboldt squid, Dosidicus gigas: implications for vertical migration in a pronounced oxygen minimum zone. Prog. Oceanogr. 86, 72-80.

Rosa, R., Yamashiro, C., Markaida, U., Rodhouse, P., Waluda, C. M., Salinas, C A., Keyl, F., O’Dor, R., Stewart, J. S. and Gilly, W. F. (2013). Dosidicus gigas,
Humboldt squid. In Advances in Squid Biology, Ecology and Fisheries: Part II Oegopsid Squids (ed. R. Rosa, G. Pierce and R. O'Dor), pp. 169-206. New York, NY: Nova Publishers.

Ryder, J. M. (1985). Determination of adenosine triphosphate and its breakdown products in fish muscle by high-performance liquid chromatography. J. Agricult. Food Chem. 33, 678-680.

Seibel, B. A. (2007). On the depth and scale of metabolic rate variation: scaling of oxygen consumption rates and enzymatic activity in the Class Cephalopoda (Mollusca). J. Exp. Biol. 210, 1-11

Seibel, B. A. (2011). Critical oxygen levels and metabolic suppression in oceanic oxygen minimum zones. J. Exp. Biol. 214, 326-336

Seibel, B. A. (2013). Critical depth in the jumbo squid, Dosidicus gigas (Ommastrephidae), living in oxygen minimum zones II. Blood-oxygen binding. Deep Sea Res. Part II Top. Stud. Oceanogr. 95, 139-144.

Seibel, B. A. and Drazen, J. C. (2007). The rate of metabolism in marine animals: environmental constraints, ecological demands and energetic opportunities. Philos. Trans. R. Soc. B 362, 2061-2078.

Shulman, G. E., Chesalin, M. V., Abolmasova, G. I., Yuneva, T. V. and Kidneys, A. (2002). Metabolic strategy in pelagic squid of the genus Sthenoteuthis (Ommastrephidae) as the basis of high abundance and productivity: An overview of the Soviet investigations. Bull. Mar. Sci. 71, 815-836.

Stewart, J. S., Field, J. C., Markaida, U. and Gilly, W. F. (2013). Behavioral ecology of jumbo squid (Dosidicus gigas) in relation to oxygen minimum zones. Deep Sea Res. Part II Top. Stud. Oceanogr. 95, 197-208.

Stewart, J. S., Hazen, E., Bograd, S. J., Byrnes, J. E. K., Foley, D. G., Gilly, W. F., Robison, B. H. and Field, J. C. (2014). Combined climate- and prey-mediated range expansion of Humboldt squid (Dosidicus gigas), a large marine predator in the California Current System. Glob. Chang. Biol. 20, 1832-1843.

Storey, K. B. (1996). Oxidative stress: animal adaptations in nature. Braz. J. Med. Biol. Res. 29, 1715-1733.

Storey, K. B. and Storey, J. M. (2004). Metabolic rate depression in animals: transcriptional and translational controls. Biol. Rev. Camb. Philos. Soc. 79, 207-233.

Storey, K. B. and Storey, J. M. (2011). Heat shock proteins and hypometabolism: adaptive strategy for proteome preservation. Res. Rep. Biol. 2011, 57-68.

Strahl, B. D. and Allis, C. D. (2000). The language of covalent histone modifications. Nature 403, 41-45.

Stramma, L., Johnson, G. C., Sprintall, J. and Mohrholz, V. (2008). Expanding oxygen-minimum zones in the tropical oceans. Science 320,655-658.

Stramma, L., Prince, E. D., Schmidtko, S., Luo, J., Hoolihan, J. P., Visbeck, M., Wallace, D. W. R., Brandt, P. and Körtzinger, A. (2011). Expansion of oxygen minimum zones may reduce available habitat for tropical pelagic fishes. Nat. Clim. Chang. 2, 33-37.

Sudhakar, A., Ramachandran, A., Ghosh, S., Hasnain, S. E., Kaufman, R. J. and Ramaiah, K. V. (2000). Phosphorylation of serine 51 in initiation factor 2 alpha (elF2 alpha) promotes complex formation between elF2 alpha(P) and elF2B and causes inhibition in the guanine nucleotide exchange activity of elF2B. Biochem. 39, 1292912938

Tessier, S. N. and Storey, K. B. (2010). Expression of myocyte enhancer factor-2 and downstream genes in ground squirrel skeletal muscle during hibernation. Mol. Cell. Biochem. 344, 151-162.

Trübenbach, K., Pegado, M. R., Seibel, B. A., and Rosa, R. (2012a). Ventilation rates and activity levels of jumbo squids under metabolic suppression in the oxygen minimum zone. J. Exp. Biol. 216, 359-368.

Trübenbach, K., Teixeira, T., Diniz, M. and Rosa, R. (2012b). Hypoxia tolerance and antioxidant defense system of juvenile jumbo squids in oxygen minimum zones. Deep Sea Res. Part II Top. Stud. Oceanogr. 95, 209-217.

Trueblood, L. A. and Seibel, B. A. (2013). The jumbo squid, Dosidicus gigas (Ommastrephidae), living in oxygen minimum zones l: oxygen consumption rates and critical oxygen partial pressures. Deep Sea Res. Part II Top. Stud. Oceanogr. 95, 218-224

Vetter, R., Kohin, S., Preti, A., McClatchie, S. and And Dewar, H. (2008). Predatory interactions and niche overlap between mako shark, Isurus oxyrinchus, and jumbo squid, Dosidicus gigas, in the California Current. CalCOFI Rep. 49, 142-156.

Wells, M. J. (1990). Oxygen extraction and jet propulsion in cephalopods. Can. J. Zool. 68, 815-824

Wouters, B. G. and Koritzinsky, M. (2008). Hypoxia signalling through mTOR and the unfolded protein response in cancer. Nat. Rev. Cancer 8, 851-864.

Zeidberg, L. D. and Robison, B. H. (2007). Invasive range expansion by the Humboldt squid, Dosidicus gigas, in the eastern North Pacific. Proc. Natl. Acad. Sci. USA 104, 12948-12950.

Zhang, J. and Storey, K. B. (2012). Cell cycle regulation in the freeze tolerant wood frog, Rana sylvatica. Cell Cycle 11, 1727-1742. 